\title{
Ecosystem-Based MSP for Enhanced Fisheries Sustainability: An Example from the Northern Adriatic (Chioggia-Venice and Rovigo, Italy)
}

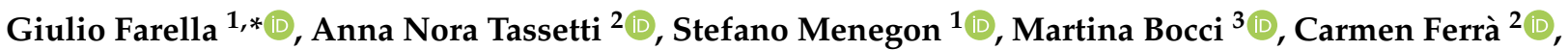 \\ Fabio Grati ${ }^{2}$, Amedeo Fadini ${ }^{1}$, Otello Giovanardi ${ }^{2,4}{ }^{\mathbb{D}}$, Gianna Fabi ${ }^{2}$, Saša Raicevich ${ }^{4}$ and Andrea Barbanti $^{1}$ (D) \\ 1 National Research Council (CNR), Institute of Marine Sciences (ISMAR), 30122 Venice, Italy; \\ stefano.menegon@cnr.it (S.M.); amedeo.fadini@ve.ismar.cnr.it (A.F.); andrea.barbanti@ve.ismar.cnr.it (A.B.) \\ 2 National Research Council (CNR), Institute for Marine Biological Resources and Biotechnologies (IRBIM), \\ 60125 Ancona, Italy; annanora.tassetti@cnr.it (A.N.T.); carmen.ferravega@cnr.it (C.F.); fabio.grati@cnr.it (F.G.); \\ otello.giovanardi@isprambiente.it (O.G.); gianna.fabi@cnr.it (G.F.) \\ 3 t-ELIKA Srl, 30133 Venice, Italy; martina.bocci@t-elika.eu \\ 4 Italian National Institute for Environmental Protection and Research (ISPRA), 30015 Chioggia (VE), Italy; \\ sasa.raicevich@isprambiente.it \\ * Correspondence: giulio.farella@ve.ismar.cnr.it
}

Citation: Farella, G.; Tassetti, A.N. Menegon, S.; Bocci, M.; Ferrà, C.; Grati, F.; Fadini, A.; Giovanardi, O.; Fabi, G.; Raicevich, S.; et al Ecosystem-Based MSP for Enhanced Fisheries Sustainability: An Example from the Northern Adriatic

(Chioggia-Venice and Rovigo, Italy) Sustainability 2021, 13, 1211. https://doi.org/10.3390/su13031211

Received: 4 December 2020

Accepted: 20 January 2021

Published: 24 January 2021

Publisher's Note: MDPI stays neutral with regard to jurisdictional claims in published maps and institutional affiliations.

Copyright: () 2021 by the authors Licensee MDPI, Basel, Switzerland. This article is an open access article distributed under the terms and conditions of the Creative Commons Attribution (CC BY) license (https:// creativecommons.org/licenses/by/ $4.0 /)$.

\begin{abstract}
Human pressures on marine ecosystems significantly increased during last decades. Among the intense anthropic activities, industrial fisheries have caused the alteration of habitats, the reduction of biodiversity and the main fish stocks. The aim of this research, carried out in the Adriatic Sea, was to test a repeatable Marine Spatial Planning framework aimed at enhancing fisheries sustainability through the application of Decision Support Tools and the composition of a catalog of possible measures. The use of these tools proved very useful to identify possible criticalities and facilitate an effective exchange with fisheries stakeholders, local authorities, and fishermen, whose involvement was an indispensable step in the process. Tool-based analyses allowed to assess the spatial footprint of a range of anthropogenic pressures from human activities (e.g., fisheries, maritime traffic, and aquaculture). Within this multi-pressure scenario, special attention was paid to fishingrelated disturbances and potential conflicts across different fishing métier and with other sectors. Specifically, results highlighted the spatial features of the major fishing pressures (e.g., abrasion from trawling) affecting essential fish habitats, marine mammals and turtles in the study area. A portfolio of possible management measures is identified for the study area. It provides clear evidence that, in order to mitigate emerging conflicts and cumulative impacts, it is necessary to combine and integrate different types of measures: spatial measures modulated over time, monitoring and control, actions to fill knowledge gaps, concertation—involvement-co-management actions, improvement of governance systems, actions to support innovation in the sector, etc. Given the complex set of measures discussed, this work can provide a useful contribution to the management of fisheries both at local and regional level, fostering the transition to sustainable fisheries.
\end{abstract}

Keywords: fisheries; ecosystem-based management; fishing activities; maritime spatial planning; cumulative effects assessment; automatic identification system-AIS; stakeholder; Adriatic Sea

\section{Introduction}

The Mediterranean Sea has been a vital source of food for human communities for centuries. During the last decades, however, the seas have experienced a significant increase in seafood demand at global scale, while the technological progress have enabled rapid industrialization of the fishing sector [1], leading to the overexploitation of fish stocks and long-term changes in coastal and marine ecosystems [2,3]. Indeed, fishing is one of the main sources of ecological disturbance [4] in the marine environment. Its geographical spread, intensity, historical, and current persistence make it one of the most relevant causes 
of biodiversity loss worldwide [5]. The extent of the cumulative effects of fishing and other relevant sources of pressures (e.g., marine pollution, alien species invasion, acidification, climate change, etc.) induced the United Nations to include the preservation of the oceans as one of the Sustainable Development Goals, namely, "Conserve and sustainably use the oceans, seas and marine resources for sustainable development" (UN-SDG 14). In the last decade, progress towards reaching fishing sustainability has been achieved in some areas such as the greater North Sea while in others, as in the case of the Mediterranean Sea, no substantial improvement has been recorded [6]. In particular, the Adriatic Sea represents an area of further concern, being this sea-basin the most exploited globally, at least considering benthic impacting gears [7], while still hosting rich biodiversity and several endemisms [8]. Fisheries affect and are affected by the natural, economic, and social environment on which they are based, and their management is inherently complex. In consequence, fisheries managers should address the impacts on the natural habitats, fish stocks, profitability of the fishing industry, together with sociocultural impacts on local communities, and political considerations [9].

The Food and Agriculture Organization (FAO) has promoted a range of positive measures to alleviate the pressure of fisheries, such as the FAO Code of Conduct for Responsible Fisheries, the adoption of the ecosystem approach to both fisheries and aquaculture, as well as the Blue Growth Initiative. Although these measures are contributing to significant successes concerning fish protein supplies, it is also clear that the sustainability of fisheries can no longer be considered in isolation from the set of human activities sharing the marine resources and space. Therefore, to ensure long-term sustainability for all activities, it has become increasingly necessary to manage marine areas throughout proper marine spatial planning [10].

In Europe, fisheries policy is an exclusive competence of the European Union. The environmental dimension of fisheries-related measures has grown over time through the continuous revision of the Common Fisheries Policy (CFP) and its alignment with other EU environmental pillars like the Birds and Habitats Directives, the Marine Strategy Framework Directive, and the Common Fisheries Policy (CFP). The aim is to create a framework for ensuring high long term fishing yields while protecting marine ecosystems. However, the EU's CFP also gives Member States the possibility e to play an active role (through the so-called "regionalization"), by submitting joint recommendations as regards the fisheries conservation measures deemed necessary to achieve those environmental objectives. The management of fisheries in a context of increasing human activities, hence, requires e systematic assessment frameworks [11] in order to put in place effective and targeted measures and reach a sounder protection of coastal and marine ecosystems [12,13].

Marine Spatial Planning (MSP) is being developed and implemented worldwide [14] and is conceived to spatially allocate and manage maritime human activities while maintaining marine ecosystems in good environmental status [15]. MSP is also designed to enhance existing management measures addressing the marine environment [16] through a proper Ecosystem Based management (EBM), that can be defined as "an interdisciplinary approach that balances ecological, social and governance principles at appropriate temporal and spatial scales in a distinct geographical area to achieve sustainable resource use" [17]. Italy transposed the EU MSP Directive (2014/89/EU) through the legislative decree n.201 in October 2016 (D. Lgs. 201/2016), establishing a national framework for MSP.

The inclusion of fisheries in the MSP process is gaining increasing attention and scientific consensus. However, MSP approaches have rarely been used for managing fisheries so far (i.e., within the Swedish Marine spatial plans for Gulf of Bothnia, Baltic Sea, and Skagerrak/Kattegat, 2019), and extensive and broad knowledge is still necessary for an effective integration of fisheries into MSP [18]. This may include quantitative knowledge on habitats, communities, and ecosystems functioning, the biology (e.g., life cycles, behavior, reproduction, interactions, and metabolism) of selected fish species at different life stages, together with frameworks and analytical approaches that allow the assessment of the spatial interactions between fisheries, other human activities, and ecosystem components [19-22]. 
Analytical approaches and decision support tools (DSTs) are diffusely used to synthesize the complex information in order to assist the decision-making process, with systematic and objective assessments of the relationships between human uses and environmental components $[23,24]$. The results from data models may strongly support fisheries management $[25,26]$ and planning [27], i.e., identifying areas with the highest level of cumulative impact [28] and assessing how human activities interact, fostering strategic choices and highlighting management priorities [29].

The reliability of these outputs is however largely dependent on the available knowledge. In particular, the knowledge on the spatial distribution of fishing activities, and the related pressures to environmental components and fisheries resources can be scarce; this restricts the availability of accurate quantitative data at proper scales limiting the provision of spatially explicit knowledge for the MSP processes [18,30].

Technological improvements may reverse such condition. For instance, the spread adoption of reporting technologies and remote sensing systems, such as vessel monitoring system (VMS) and automatic identification system (AIS), are generating an overwhelming amount of reliable, spatio-temporal and geographically distributed data related to large-size vessels and their movements, which could enhance the maritime knowledge if analyzed and modeled [31-34].

The extraction of spatially-explicit information from these data, especially in connection with machine learning techniques, is thus a key element to offer operational authorities, policy-makers, and scientists a better picture of what is happening at sea [35-37]. Moreover, the use of these layers of information to feed DSTs provides a substantial opportunity for planners to develop long-term strategies and support sustainable growth in the maritime sectors as a whole [38-40].

In this context, this research aimed to test a complete and repeatable MSP assessment framework with a specific focus on fishing activities, fish resources and protected species and habitats. In line with the EBM approach, the assessment framework proposed in this research considers the analysis of a complex system of multiple anthropogenic pressures derived from the uses of the sea and the coast in the Chioggia compartment. The conflicts among the various uses of the sea space (including the different segments of fisheries) were evaluated and the ecological impact of sea uses on key environmental receptors (benthic ecosystems, cetaceans and marine turtles, spawning and nursery areas) were assessed. The assessment framework includes (i) the reconstruction of a complete knowledge framework for the case study area; (ii) the analysis of the interactions between fishing and other uses of the sea and the impacts on environmental components; (iii) the identification of the main issues to be addressed. The results from this analyses were used to identify a portfolio of management measures focused on fisheries, aimed at minimizing environmental impacts and enhancing synergies with other coastal and maritime uses. Particular focus was given to the support offered by the application of existing DSTs to the whole process. The whole process was also developed engaging fishermen and stakeholders through specific activities. Within the research, strictly connected to the ongoing elaboration of the maritime spatial plans in the Italian seas, we discussed the needs of complex measures scenarios in order to maintain/improve the fisheries system while reducing its pressures on habitats, species and ecosystem within the context of the overall system of human uses in the area.

\section{Materials and Methods}

\subsection{Case Study: Environmental Features, Human Activities, Existing Environmental, and Resources Protection Measures}

The Adriatic Sea is a semi-enclosed basin; its northernmost part is characterized, on the western side, by the presence of a system of deltas and lagoons (between the Rivers Po and Isonzo) which formed 6000 years ago, whereas the Eastern coast is high and rocky [41]. In the western area, the shallow depth (mean depth of $33.5 \mathrm{~m}$ ) and the presence of incoherent sediments (muddy to sandy), make the Northern Adriatic Sea a vast trawlable area. Given the abundance of fisheries resources associated with the high productivity (triggered by the Po river discharge), there is a strong fishing tradition in this 
area [42]. The Northern Adriatic Sea is also characterized by the occurrence of species of high conservation interest, like the sea turtle Caretta caretta and the cetacean Tursiops truncatus. A few rocky outcrops (locally named tegnùe in the Venetian dialect) [43] with high biodiversity value and sensitivities are also present. The coastal areas, and the system of deltas and lagoons, are nursery areas with a relevant role for the essential fish habitat of several target species (e.g., red mullet, seabass, sea bream, and cuttlefish) [44].

The coastal city of Chioggia hosts the largest Italian fishing fleet and the fisheries resources (both benthic and pelagic stocks) are severely overexploited in the whole Adriatic Sea basin [45]. Aquaculture is also a relevant activity, with the presence of mussel farms along the Italian coastal area. The study area (Figure 1) is close to the industrial site of Porto Marghera and the commercial port of Venice, which generate intense marine traffic. The city of Venice itself, and the coastal areas, are particularly relevant in terms of tourist activities, including marine yachting. The study area hosts two Natura 2000 sites, the "Tegnue di Chioggia" and the "Adriatico Settentrionale Veneto-Delta del Po". Other neighboring Natura 2000 sites were established to protect coastal lagoons and deltas. Typical measures established to limit fishing pressures include the permanent exclusion of bottom and pelagic trawling from the coast towards three nautical miles (according to the so-called Mediterranean Regulation, Reg. CE 1967/2006), and the establishment of a summer trawling fishing ban lasting around 45 days aimed at protecting recruits.

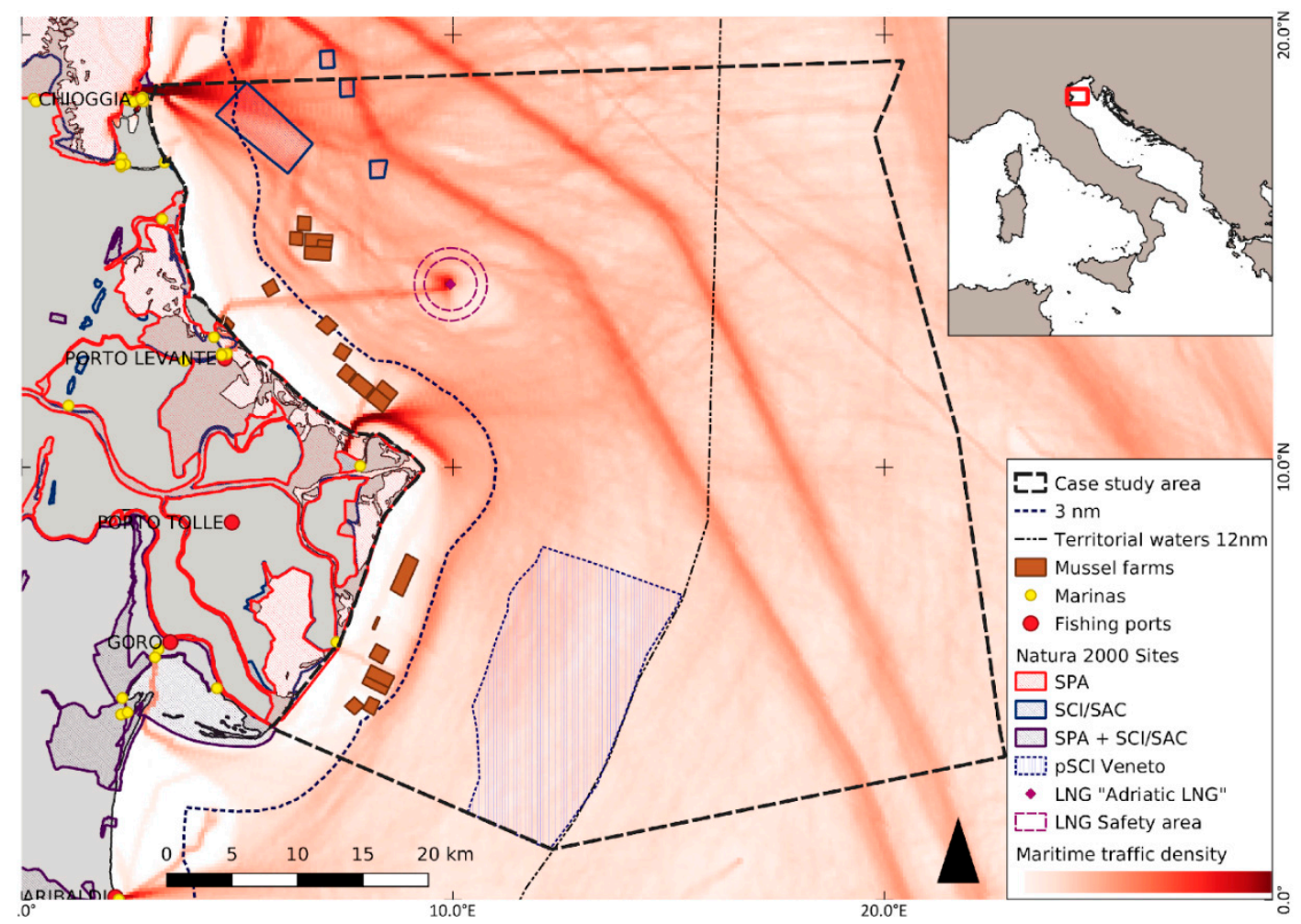

Figure 1. Case Study boundaries and features.

Considering a broader scale, the Northern-Central Adriatic coastline hosts other major industrial ports and sites (e.g., Trieste, Ravenna, Ancona, Koper, and Rijeka), that along with touristic pressure (and fishing) makes the basin the most affected by cumulative human pressures in the Mediterranean Sea [46]. 


\subsection{Analyses}

\subsubsection{AIS Data Processing}

AIS data at 5-min resolution were first filtered to identify vessels likely to be fishing within the study area at least once during 2015. After a preliminary data inspection, AIS data were processed as follow (Figure 2):

- Raw Data Cleaning: identifying and editing/deleting outliers, such as pings in land and/or far away from preceding and following transmissions;

- Fishing trip identification: partitioning strings of consecutive AIS records for each unique Maritime Mobile Service Identity (MMSI) into individual trips, from the time vessels leave a port to the time they return to a port. An ad-hoc algorithm was developed in Matlab software to identify individual trips, requiring a number of nuanced steps to fix data issues, such as missing AIS transmissions in close proximity to ports and vessels steaming near the coast. Fishing trips were stored in the spatial database along with inherited geographical attributes (ports, countries, and GSAs of departure and landing) and additional trip metrics were computed such as duration and percentage of data gaps due either to intentional switch off by fishermen or transmission issues (i.e., in regions with high maritime traffic or missing terrestrial receivers along the coastlines).

- Assignment of the fishing gear: a rule-based machine learning was used to characterize single trips and to identify the type of fishing, based on GPS values and profiles of speed and course and additional gear-specific movement patterns (e.g., duration of the fishing trip and operations, course values during the hauling, and time gap between subsequent hauls). A set of algorithms were developed using Matlab software environment to incorporate prior domain knowledge for different gear types and executed in sequence to label single trips according to predefined gear classes: bottom otter trawl, beam trawl, pelagic trawl, purse seine, longline, and "other" fishing (including nets and traps).

- The algorithms were designed for each of the predefined gear classes and then a rule-based decision was taken to uniquely assign a gear type to each month on the basis of single answers (given by algorithms for each trip). Decisions were taken on a monthly basis and weighting only "stable" fishing trips that were more robustly classified, such as those with at least 30 transmissions and with a percentage of data gaps non-exceeding $90 \%$. Given the above, the current rule-based system was able to question trip-level outliers (i.e., erroneous gear detection due to a poor data coverage), impose the predominant monthly gear type in use and/or validate real changes in fishing behavior, such as when vessels rotate fishing gears.

- Fishing segment identification: once trips had been labeled according to the gear type, hauls were extracted when fishing vessels were likely engaging in fishing operations. Extracted fishing segments were stored in the single spatial database and ready to be aggregated and binned into grid cells. Segments were stored along with their attributes (MMSI, number of pings, speed class, distances, and duration) and related parent tables (trip ID and raw pings).

- Finally, the intensity of fishing operations was mapped on a monthly and yearly basis and the output was represented on $1 \mathrm{~km} \times 1 \mathrm{~km}$ grid cells, and populated with different metrics of fishing effort (i.e., fishing time and swept length). Annual/monthly fishing effort estimates were quantified in each grid cell spatial joining overlapping portions of hauls, and summing relative durations and lengths. 


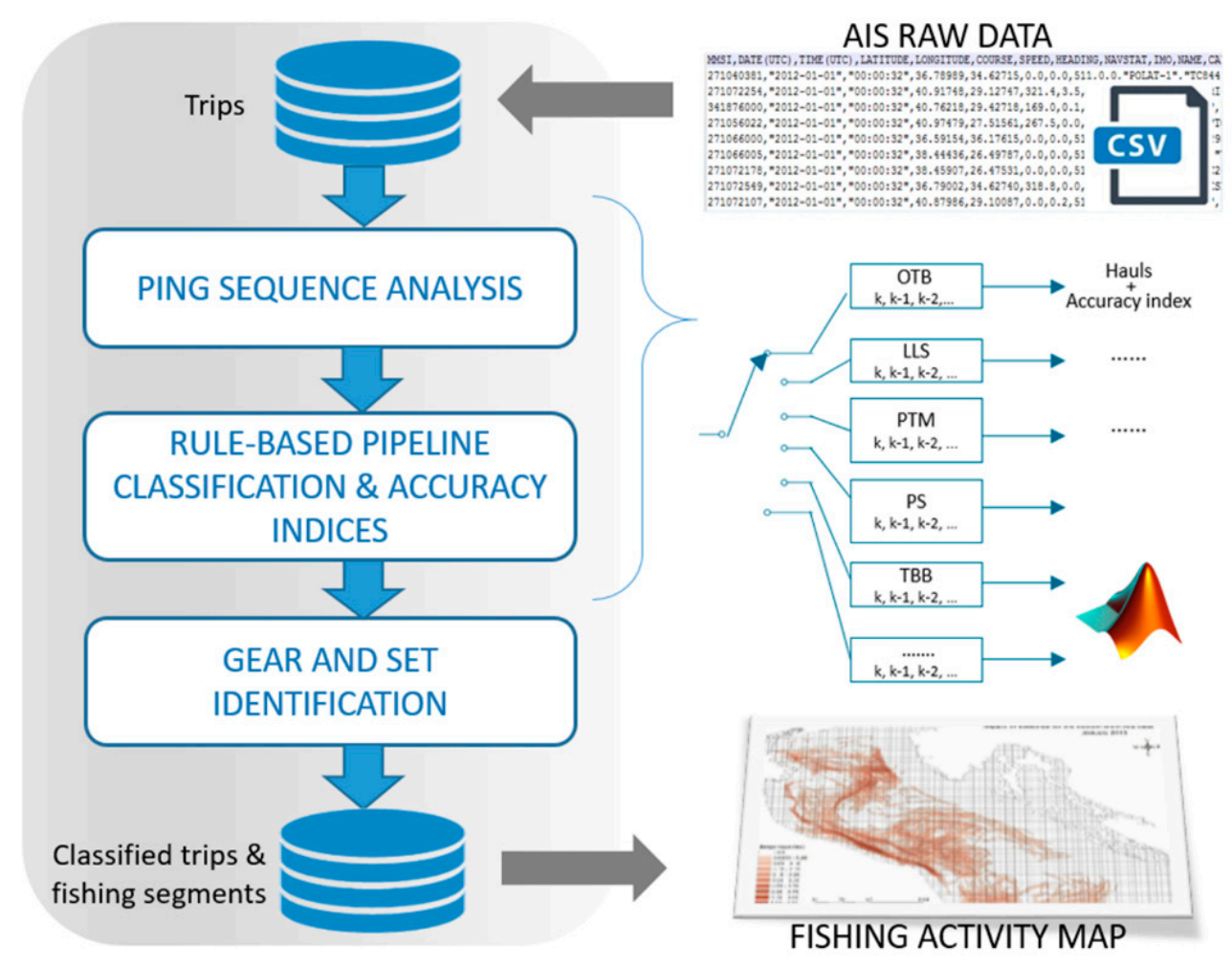

Figure 2. Simplified representation of the automatic identification system (AIS) data processing.

\subsubsection{Data Collection and Preparation for DST}

The geospatial dataset implemented for the study is composed of multi-source geospatial information from different regional (e.g., Veneto Region) and EU level data providers (i.e., EMODnet, Tools4MSP; [47-49]). The dataset includes 13 human uses (U) and 4 environmental components (E).

Tables 1 and 2 present a detailed overview of the geospatial dataset involved in the analysis. All datasets have been rasterized in a regular grid with cell resolution of $250 \mathrm{~m} \times$ $250 \mathrm{~m}$. The units of the spatial indicators $\mathrm{U}$ and $\mathrm{E}$ are presence/absence (i.e., aquaculture), weighted dummy (i.e., land-based activities) and intensity indicators (i.e., maritime traffic). Intensity indicators were transformed using $\log [x+1]$ to avoid an over-dominance of extreme values and all datasets rescaled from 0 to 1 to allow direct comparison on a single, unit-less scale $[46,50]$.

Table 1. Human uses (U) geospatial data. Note: $\mathrm{P} / \mathrm{A}=$ Presence/Absence.

\begin{tabular}{|c|c|c|c|}
\hline Human Use & Description & Unit & Source \\
\hline Aquaculture & $\begin{array}{l}\text { Aquaculture (Veneto } \\
\text { Region-2015) }\end{array}$ & $\mathrm{P} / \mathrm{A}$ & Veneto Region-2015 \\
\hline Cables and Pipelines & LNG submarine pipelines & $\mathrm{P} / \mathrm{A}$ & Veneto Region-2015 \\
\hline \multirow{2}{*}{ Coastal and Maritime Tourism } & Bathing waters & $\mathrm{P} / \mathrm{A}$ & SHAPE Project \\
\hline & Marinas-Italy & Nr of berth & $\begin{array}{c}\text { PagineAzzurre.com } \\
\text { (elaboration Tools4MSP) }\end{array}$ \\
\hline Land Based Activities & $\begin{array}{l}\text { Modeled land based pressures } \\
\text { from rivers into the Adriatic } \\
\text { Sea }\end{array}$ & $\begin{array}{l}\text { Index }(1-\text { high contribution to } \\
0-\text { no contribution })\end{array}$ & $\begin{array}{c}\text { SHYFEM (Shallow water } \\
\text { Hydrodynamic Finite Model) }\end{array}$ \\
\hline $\begin{array}{l}\text { Liquefied natural gas plant } \\
\text { (LNG) }\end{array}$ & LNG terminal "Adriatic LNG" & $\mathrm{P} / \mathrm{A}$ & Veneto Region-2015 \\
\hline
\end{tabular}


Table 1. Cont.

\begin{tabular}{|c|c|c|c|}
\hline Human Use & Description & Unit & Source \\
\hline Maritime Transport & $\begin{array}{l}\text { Adriatic traffic density July } \\
\text { 2014-June } 2015\end{array}$ & Ship passages/cell & $\begin{array}{c}\text { BALMAS project } \\
\text { (www.balmas.eu), elaboration } \\
\text { Tools4MSP }\end{array}$ \\
\hline \multirow[b]{2}{*}{ Naval base activities } & Cruise Ports 2015 & Nr of cruises & [47] \\
\hline & $\begin{array}{l}\text { Main Ports (Total shipped } \\
\text { goods) 2015-2016 }\end{array}$ & Tons & [47] \\
\hline Oil \& Gas extraction & $\begin{array}{l}\text { EMODNET Hydrocarbon } \\
\text { Extraction-Offshore } \\
\text { Installations }\end{array}$ & $\mathrm{P} / \mathrm{A}$ & [47] \\
\hline Small scale fishery & $\begin{array}{c}\text { Small scale fisheries (e.g., Set } \\
\text { gillnets, purse seines, traps, } \\
\text { etc.) }\end{array}$ & Total operations & FAO-ADRIAMED data, 2015 \\
\hline Hydraulic dredges & $\begin{array}{l}\text { Hydraulic dredges for clam } \\
\text { fisheries }\end{array}$ & Total operations & [49] \\
\hline $\begin{array}{l}\text { Mid-water pelagic trawling } \\
\text { (PTM) }\end{array}$ & Pelagic trawl from AIS 2015 & Swept length $(\mathrm{km})$ & See Section 2.2.1 \\
\hline Bottom trawling (OTB) & $\begin{array}{l}\text { Bottom otter trawl from AIS } \\
\qquad 2015\end{array}$ & Swept length $(\mathrm{km})$ & See Section 2.2.1 \\
\hline Beam trawling (TBB) & Beam trawl from AIS 2015 & Swept length $(\mathrm{km})$ & See Section 2.2.1 \\
\hline
\end{tabular}

Table 2. Environmental components (E).

\begin{tabular}{|c|c|c|c|}
\hline Environmental Component & Description & Unit & Source \\
\hline \multirow{7}{*}{ Marine seabed habitats } & $\begin{array}{c}\text { EUNIS A4.26- } \begin{array}{c}\text { Mediterranean coralligenous } \\
\text { communities }\end{array}\end{array}$ & \multirow{7}{*}{$\mathrm{P} / \mathrm{A}$} & \multirow{7}{*}{ [48] } \\
\hline & EUNIS A5.23-Infralittoral fine sands & & \\
\hline & EUNIS A5.25-Circalittoral fine sands & & \\
\hline & EUNIS A5.26-Circalittoral muddy sand & & \\
\hline & EUNIS A5.33-Infralittoral sandy mud & & \\
\hline & EUNIS A5.35-Circalittoral sandy mud & & \\
\hline & EUNIS A5.36-Circalittoral fine mud & & \\
\hline MM-Marine mammals & $\begin{array}{l}\text { Tursiops truncatus predicted density in the } \\
\text { Adriatic Sea (2010-2013) }\end{array}$ & $\begin{array}{c}\text { Density }(\mathrm{nr} \text { of } \\
\text { animals } / 100 \mathrm{~km}^{2} \text { ) } \\
\text { categories }\end{array}$ & [51] \\
\hline \multirow{10}{*}{ EFH_Essential Fish Habitats } & $\begin{array}{l}\text { Engraulis encrasicolus (European anchovy) } \\
\text { spawners }\end{array}$ & \multirow{10}{*}{$\begin{array}{l}\text { Probability of } \\
\text { occurrence }\end{array}$} & \multirow{10}{*}{$\begin{array}{l}\text { MAREA-MEDISEH } \\
\text { Project [52] }\end{array}$} \\
\hline & Pagellus erythrinus (Common Pandora) recruits & & \\
\hline & Solea solea (Common sole) recruits & & \\
\hline & $\begin{array}{l}\text { Trachurus mediterraneus (Mediterranean horse } \\
\text { mackerel) recruits }\end{array}$ & & \\
\hline & $\begin{array}{c}\text { Trachurus trachurus (Atlantic horse mackerel) } \\
\text { recruits }\end{array}$ & & \\
\hline & Sardina pilchardus (European pilchard) spawners & & \\
\hline & Scomber colias (Atlantic chub mackerel) spawners & & \\
\hline & Scomber colias (Atlantic chub mackerel) recruits & & \\
\hline & Scomber scombrus (Atlantic mackerel) recruits & & \\
\hline & Mullus barbatus (Red mullet) recruits & & \\
\hline
\end{tabular}


Table 2. Cont

\begin{tabular}{|c|c|c|c|}
\hline Environmental Component & Description & Unit & Source \\
\hline & $\begin{array}{c}\text { Engraulis encrasicolus (European anchovy) } \\
\text { recruits }\end{array}$ & & \\
\hline & Sardina pilchardus (European pilchard) recruits & & \\
\hline & Solea solea (Common sole) spawners & & \\
\hline TU-Turtles & $\begin{array}{l}\text { Caretta caretta predicted density in the Adriatic } \\
\text { Sea (2010-2013) }\end{array}$ & $\begin{array}{c}\text { Density }(\mathrm{nr} \text { of } \\
\left.\text { animals } / 100 \mathrm{~km}^{2}\right) \\
\text { categories }\end{array}$ & [51] \\
\hline
\end{tabular}

According to the MSFD Annex III (2017/845/EU), a total 15 anthropogenic pressures were investigated. The pressures' propagation from the sources followed various modeling approaches. Land based pressures (i.e., inputs of fertilizers and other nitrogen and phosphorus-rich substances, inputs of organic matter, and introduction of non-synthetic substances and compounds and other substances) from coastal anthropized areas were modeled using the open-source 3-D hydrodynamic model SHYFEM (Shallow water Hydrodynamic Finite Model) [53], reproducing the dynamics of substances from catchment basins into the Adriatic Sea [54]. In absence of specific and robust knowledge on the pressure propagation, we adopted an isotropic convolution function [21]. Detailed description of the pressure indicators and propagation models can be found in Menegon et al. [50] and Farella et al. [55].

\subsubsection{Maritime Use Conflict (MUC) Analysis}

Maritime use conflict analysis (MUC) was performed in order to analyze current interactions between human uses and to locate conflict areas, guiding in the structuring of planning processes that can support sustainable ocean zoning [56]. Tools4MSP MUC methodology is developed within the Tools4MSP Modelling Framework [57], an MSP-oriented open source software suite for geospatial analysis, which provides a multiobjective tool-set for MSP, and enables the identification of current/potential human uses and assesses their interaction in terms of conflicts. The MUC score on a single grid of analysis is calculated summing the potential conflict score between each combination of uses which are present in that cell (Equation (1)).

$$
M U C=\sum_{i=1}^{l} \sum_{j=1+1}^{l} c_{i, j} p\left(U_{i}\right) p\left(U_{j}\right)
$$

where

$c_{i, j}=$ potential conflict score between $U_{i}$ and $U_{j}$. It can vary from 0 (no conflict) to 6 (very high conflict score).

$p\left(U_{i}\right)=$ presence $(1)$ or absence $(0)$ of the $i$-th human use in the cell.

$p\left(U_{j}\right)=$ presence $(1)$ or absence $(0)$ of the $j$-th human use in the cell.

For a more detailed description of the MUC assessment we refer to Depellegrin et al. [54] and Menegon et al. [50].

\subsubsection{Cumulative Effect (CEA) Analysis}

The cumulative effects assessment (CEA) model applied in this research is based on the Tools4MSP Modelling Framework [57]. CEA is defined as a systematic procedure for identifying and evaluating the significance of effects from multiple pressures and/or activities on single or multiple receptors [58]. The algorithm is described in Equations (2) and (3) as follows:

$$
C E A=\sum_{k=1}^{n} d\left(E_{k}\right) \sum_{j=1}^{m} s_{i, j} e f f\left(P_{j} E_{k}\right)
$$


where eff is the effect of pressure $P$ over the environmental component $E$ and it is defined as follows:

$$
\text { eff }\left(P_{j} E_{k}\right)=r f u n c_{j, k}\left(\sum_{i=1}^{l} w_{i, j} i\left(U_{i}, M_{i, j, k}\right)^{\prime}\right)
$$

whereas

$U_{i}$ defines the human uses active in the study area (Table 1);

$E_{k}$ defines the environmental components of the study area (Table 2);

$\mathrm{d}\left(E_{k}\right)$ defines intensity or presence/absence of the $k$-th environmental component;

$P_{j}$ defines the 15 MSFD pressures exerted by human activities according to (EC, 2017, Annex III, Table 2);

$w_{i, j}$ refer to the use-specific pressure weight [55];

$\mathrm{s}\left(P_{j} ; E_{k}\right)$ is the sensitivity of the $k$-th environmental component to the $j$-th pressure [55], defined as the combination of the direct and indirect impact of a pressure, the degree of disturbance generated on the key ecological features and the recovery time of environmental components exposed [54];

$\mathrm{i}\left(U_{i}, \mathrm{M}\left(U_{i}, P_{j}, E_{k}\right)\right)$ distance model propagating $j$-th pressure caused by $i$-th activity over the k-th environmental component;

$\mathrm{M}\left(U_{i}, P_{j}\right) 2 \mathrm{D}$ gaussian kernel function used for convolution (buffer distances at $1 \mathrm{~km}$, $5 \mathrm{~km}, 10 \mathrm{~km}, 20 \mathrm{~km}$, and $50 \mathrm{~km})$ [57];

rfunc $j, k$ defines the response function of the $k$-th environmental component to a $j$-th pressure. Identity function has been adopted for all $j, k$ combination.

\subsubsection{Stakeholder Engagement}

Being fundamental for any planning process (according to MSP Directive 2014/89 $\mathrm{EU}$, art. 21) [59-61], fishing operators and other relevant stakeholders were involved to analyze the issues relevant to the Compartment and identify possible measures. To this end, participatory workshops were organized. Three meetings (July 2018, November 2018, and May 2019) were held with fishing operators and invitations were extended to a selection of other stakeholders (municipalities, port authorities, aquaculture and tourism operators, recreational fishing groups, researchers, and NGOs). During these meetings the objectives and results of the study were illustrated and feedback from the participants was noted in real time, so as to make it immediately visible to all [62].

In addition, questionnaires were used to collect stakeholders' input. They were distributed during the meetings, and the participants were asked to fill them in on the spot. In this way, a more personal and private space for participation was offered, aiming to collect those ideas that might not be expressed because of existing tensions and conflicts between the categories of participants.

\subsection{Management Framework Proposal}

The study focused on the sustainability of fishing activities within the overall framework of the present coastal and marine human uses. The pivotal objective was the definition of a set of management proposals, responding to the following criteria: (i) maintaining/increasing the environmental sustainability of fisheries; (ii) preserving fisheries profitability and, possibly, stimulate the growth and development of the sector; (iii) reducing conflicts among marine uses and between different fishing sectors; and (iv) exploiting/leveraging potential synergies. The overarching vision was to ensure that fishing activities in the case study (CS) area do not compromise the marine environment and its resources, fostering a sustainable and balanced development of the sea space.

The specific planning objectives took into account the governance system (e.g., national waters within the $12 \mathrm{~nm}$, and international waters and national continental shelf offshore the $12 \mathrm{~nm}$ ), and the already established and proposed conservation measures (from Biological Protection Zones to Natura 2000 sites).

In line with the EU legal framework, in particular with the Marine Strategy Framework Directive (MSFD, CE/2008/58) GES prescriptions for Descriptors 1 (Biodiversity), 
3 (Commercial Fish and shellfish) and 6 (Sea-floor integrity) (2017/848/EU), specific environmental management measures were designed taking into account the safeguard of protected species and habitats, also including the Essential Fish Habitats (EFHs) of species of high commercial value, defined as areas where recruits/adults concentrate (i.e., nursery/potential spawning areas), within of the overall strategy addressing biodiversity conservation.

The priority issues for local fisheries were identified taking into account the conflicts and potential multiple impacts by analyzing the distribution of (1) CEA and (2) MUC scores. The MUC analysis highlighted the fishing sectors characterized by the highest conflicts (across fishing activities and with other uses of the sea) while CEA permitted to identify those whose effect was deemed to be more pervasive on specific environmental components. Through these analyses, it was possible to identify priority measures whose application could result in the reduction of conflicts and impacts in the case study area.

The range of measures considered was extended considering both expert-based knowledge in the area, and through the engagement of fisheries stakeholders in public meetings (see Section 2.2.5).

\section{Results}

3.1. Overall Results

\subsubsection{Fishing Activity from AIS Data}

AIS allowed capturing large trawler's activities (170 fishing vessels, trawling at least once in 2015 within the compartment of Chioggia), while fishing activity with passive gears was underrepresented. This is because this fishery, based on the use of set nets and traps, is mostly carried out with small fishing vessels not adopting AIS. This fraction represents $68 \%$ of the whole registered fleet.

With regards to vessels equipped with AIS, bottom trawlers were dominant in the studied area, followed by beam and pelagic trawlers (79,50 and 48 trawlers, respectively). Only three "other" vessels were identified and consisted of one dredge and two vessels supporting mussel farming sites.

Bottom and beam trawling footprints revealed to be habitat-dependent, with highly impacted grounds which leave well-known spatial patterns of benthic assemblages' distributions uncovered [63] (Figure 3a,b). By contrast, AIS detected pelagic trawlers' activities throughout the whole district (Figure 3c), and purse seiners only fishing outside its southern borders. Most vessels were found to be registered in the Chioggia compartment itself or in vicinity of its border, while only a very small number of trawlers (mostly beam trawling (TBB)) were tracked while leaving and/or returning ports further away from the case study area (e.g., ports of Venice, Pesaro, and Ancona).

The high spatial resolution of the AIS data allowed to assess the partial compliance to regulations, including the summer fishing ban (Ministerial Decree 03/07/2015; Figure $3 \mathrm{~d}$ ), and the measures banning all the activities in close proximity of offshore structures (i.e., Adriatic Liquefied Natural Gas Terminal) and managing fishery in specific areas (SAC/BPA). Indeed, AIS data confirmed the propensity of trawlers to concentrate close to the regulated areas, actual entering/fishing within $3 \mathrm{~nm}$ from the coast or inside the BPA Tenue Chioggia. 


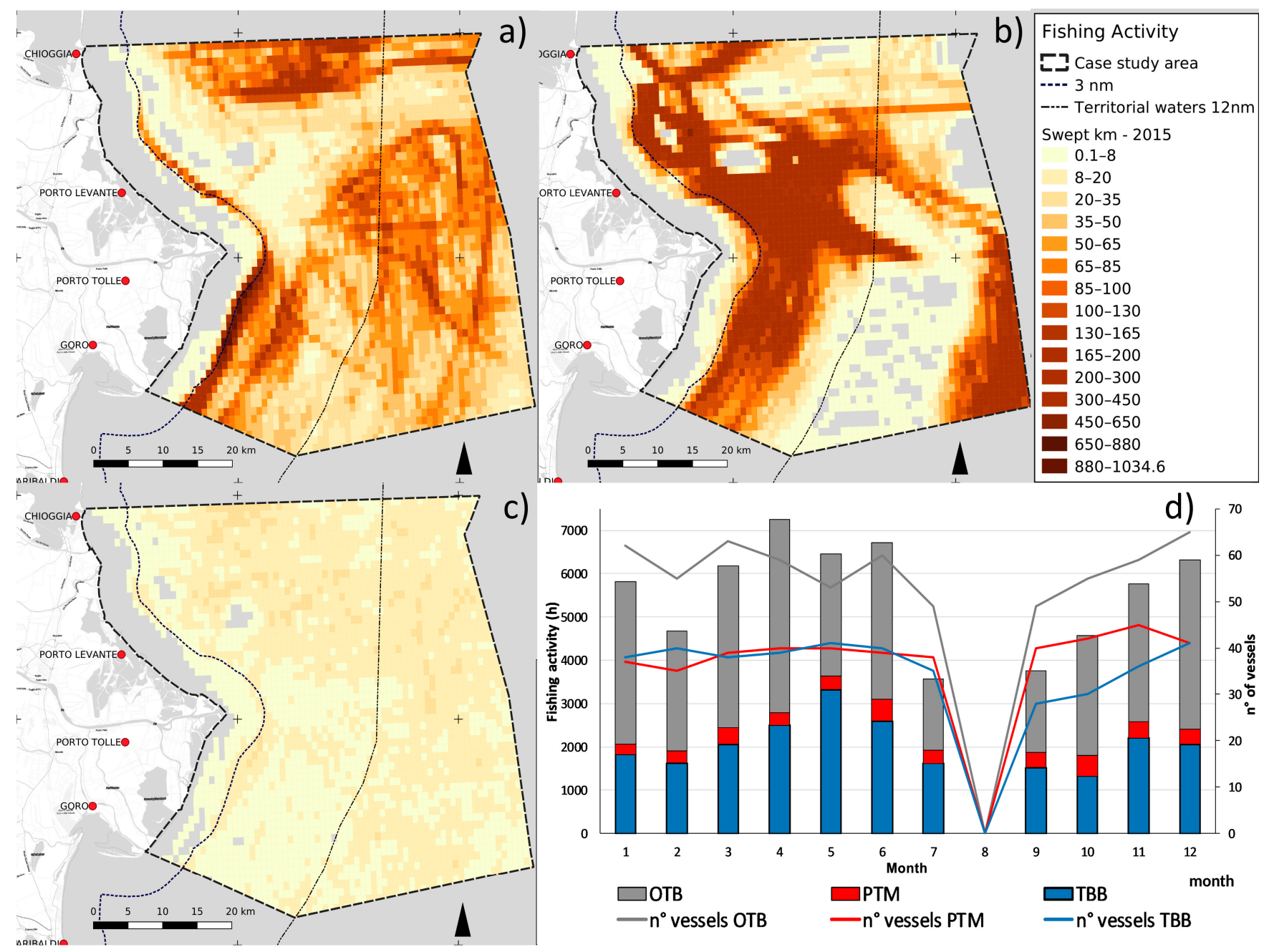

Figure 3. Annual AIS-derived fishing footprint of trawlers throughout the case study area: (a) bottom trawlers (OTB); (b) "rapido" beam trawlers (TBB); (c) pelagic trawlers (PTM); (d) Fishing hours and number of vessels by gear and month (year 2015).

\subsubsection{Maritime Use Conflict (MUC) Analysis}

Figure 4a reports the results obtained from marine use conflict analysis. The highest MUC scores are within the national waters $(3 \mathrm{~nm})$, in the presence of a high concentration among highly conflicting uses, while offshore conflicts are mainly linked to overlaps between the different types of trawl fisheries crossing the main maritime traffic routes. 


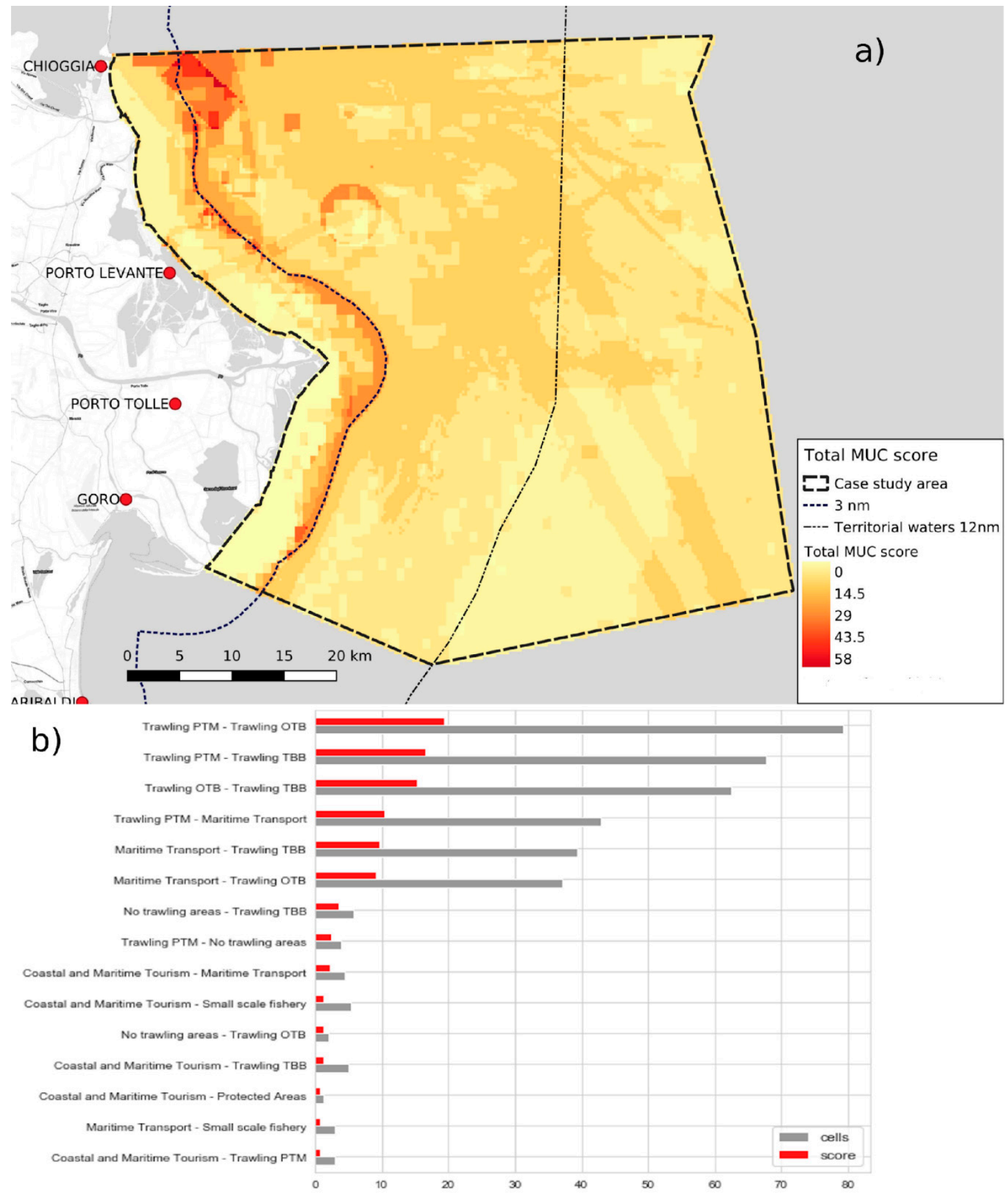

Figure 4. Maritime Use Conflict (MUC) model application: (a) spatial distribution of MUC scores; (b) spatial coverage of the contributions (in \% of the CS cells; gray bars) of the single pairwise combinations to the total MUC score for the whole area of analysis, and relative percent contribution to the total MUC score (red bars).

The higher scores are linked to the interactions between different trawling fleets (TBB, PTM, and OTB), contributing to over $50 \%$ of the total MUC score. Following, the interaction between maritime traffic and trawl fisheries (28\%) exerted along the borders of the extensive no trawling zones (due to environmental protection and fishery management and other human activities such as LNG and aquaculture) and trawl fisheries (9\%). Other relevant potential conflicts are those between coastal and maritime tourism with maritime transport, coastal and maritime tourism with small-scale fisheries, and between trawl and small-scale fisheries (Figure $4 b$ ). 


\subsubsection{Cumulative Effect (CEA) Analysis}

The spatial explicit outputs of the CEA application are shown in Figure 5a. Highest scores (20-30) are located in the whole case study area, where intense maritime traffic areas, highly trawled fishing grounds and hot spots of species (i.e., marine turtles and mammals) and habitats (e.g., the circalittoral bio-constructions called tegnùe) of conservation interest occur: between 3 and $10 \mathrm{~nm}$ offshore, in a relatively small area in International waters (approximately $20 \mathrm{~nm}$ offshore) and close to the port of Chioggia. Areas showing mediumhigh scores (10-20) are widely spread along the area, mainly due to maritime traffic and trawling activities, while coastal areas far from ports and marinas and within the $3 \mathrm{~nm}$, where trawl fisheries are banned with the significant exception of the areas subject to fishing with hydraulic dredges, feature lower CEA scores $(<10)$.
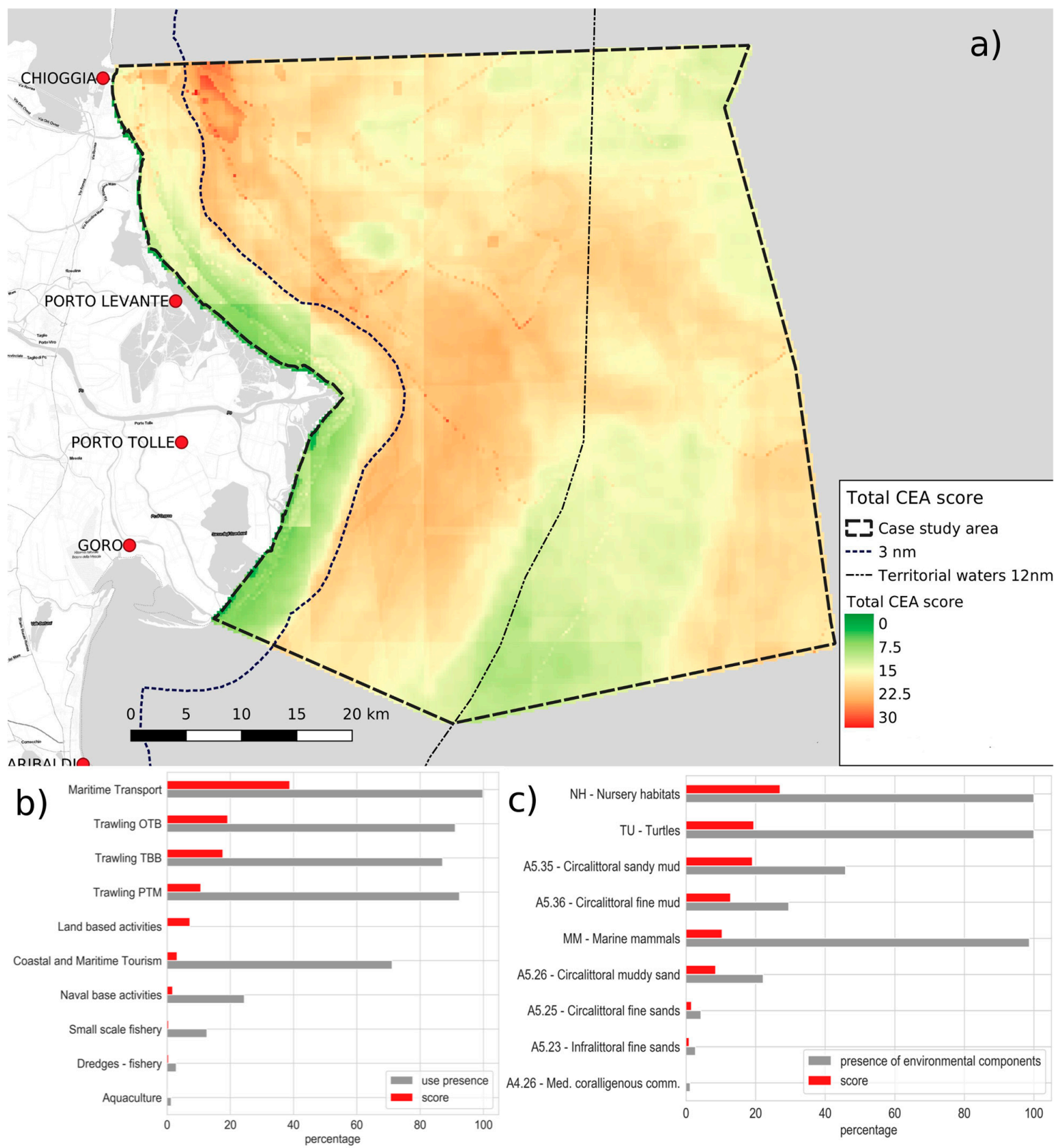

Figure 5. Cumulative Effect (CEA) model application: (a) spatial distribution of CEA scores; (b) spatial coverage of maritime uses presence in the study area (\% of the CS cells; gray bars) and percent contribution of the maritime uses' pressure to the total CEA score (red bars); (c) spatial presence of environmental components in the study area (\% of the CS cells; gray bars) and relative contribution to the total CEA score (red bars). 
In the CS area, the full set of trawling activities causes the higher total CEA score $(50 \%)$. In particular, bottom otter trawlers (OTB) generate the $19 \%$ of the total CEA score, while both "rapido" beam trawlers (TBB) and mid-water pelagic (PTM) exert pressures for a contribution to the total CEA score of the $18 \%$ and $11 \%$, respectively (Figure $5 \mathrm{~b}$ ). On the other side, small-scale fisheries exerts less than the $2 \%$ of total CEA score while they are present in the $12 \%$ of the area (mainly within the $3 \mathrm{~nm}$ ).

The complex system of maritime traffic is the most widespread human use, covering almost $100 \%$ of the CS cells, and represent the second main source of human pressures ( $40 \%$ of the total CEA score), while port activities in the area are concentrated close to the city of Chioggia, exerting low CEA scores ( $0.3 \%$ of the total).

The LNG plant, while contributing less than the $1 \%$ to the overall CEA score for the entire area, determine the highest single-cell CEA score value, generating related pressures mainly due to the introduction of substances into the sea (i.e., chlorinated waters) and underwater noise that spread from the source for a radius of about five $\mathrm{km}$.

Land sourced anthropogenic pressures are strongly related to riverine inputs (e.g., Po river) and have a significant contribution to the overall CEA score $(>6 \%)$, with higher scores within the $6 \mathrm{~nm}$ offshore. Spatial extent and/or intensities of other important human activities (e.g., coastal and maritime tourism, hydraulic dredges fisheries, and aquaculture) are lower, with lesser contributions to the total CEA score $(<2 \%)$, even if high absolute scores may be found in their proximity.

Nursery and spawning areas of species of commercial interest for fisheries (EFHs) are widespread in the whole area and represent the environmental components more exposed to anthropogenic pressures (e.g., abrasion, pollution, and marine litter; $31.1 \%$ of the total CEA score). The whole set of human activities (especially trawling and traffic) generate a high cumulative effect score $(13.6 \%)$ on C. caretta, present in the whole CS area with high seasonal variations. Marine mammals are similarly affected even though to a lower extent $(9.7 \%)$ due to both lower densities and sensitivities to specific pressures (Figure $5 c$ ).

Both muddy (represented in the $64 \%$ of the CS area) and sandy (36\%) seabeds are also highly exposed to the analyzed pressures (e.g., abrasion, pollution, and marine litter) in the area (23.1\% of the total CEA score).

The rocky bottoms and coralligenous communities are also influenced by numerous pressures that propagate from various activities but show low CEA scores due to the protection and trawling bans of the tegnùe area.

\subsection{Management Framework Proposal}

\subsubsection{Priorities for Long-Term Sustainable Fisheries in the Area}

Environmental protection and lasting socio-economic development combine to define a model of sustainable management of fishing activities that preserves fish resources in the long term, protects the good state of marine species and ecosystems, guarantees the livelihood of operators, and allows conservation of practices, knowledge, and crafts for the benefit of coastal communities.

On the basis of the results derived from available knowledge (literature analysis and collected data) and from the application of the analysis tools, as well as from the interaction with fishing operators and with other stakeholders, a series of issues considered as priorities for the sustainable management of fishing activities have been identified, as reported in Table 3.

Table 3. List of priorities for long-term sustainable fisheries in the area.

\section{Title}

Conflicts between fishing segments

Sustainability of fishing effort

\section{Description}

Conflicts exist between small-scale fishing and bottom trawling and between different types of bottom trawling.

Spatial, temporal, and space-time measures for the sustainable management of fishing activities are already in place. These actions need to be updated, based on results achieved so far and new policies.

C Rules enforcement Effectiveness of the measures in place is compromised by infringements.


Table 3. Cont.

Title

$\mathrm{D}$

Impacts of fisheries on vulnerable species and valuable environmental components
Description

Techniques and practices can be developed and tested, also with the contribution of operators, to minimize the negative effects of fishing on some species in particular (e.g., bottlenose dolphins, turtles, and non-target fish species), on habitats (e.g., bioconstructions, bottom communities) or ecosystems.

Fragmentation in the sector impairs innovation and the diversification capacities, makes it less representative in decision-making contexts, and increases internal conflicts.

The study area is used not only by local fisheries but also by fisheries from neighboring fishing ports, such as Rimini and Cesenatico (Emilia-Romagna Region) and Ancona (Marche Region). Furthermore, there is competition for resources and shared markets with foreign fisheries, in particular with the Croatian one. When the space-time regulations in place are different, disadvantages-and consequently conflicts-may arise for one or the other part.

In a context of lower and lower profitability in the sector, developing innovative activities, complementary to fishing, represents an opportunity for integration of income. The environmental, historical and cultural richness of the case study area creates a favorable context for the development of synergies between the fishing sector and other uses of the sea such as tourism and recreation.

The current organization of product distribution-including competition from abroad-determines the race for lower and lower prices. With higher value of product, catches could be reduced because fishermen could get the same income with a lower number of fishing days.

$\mathrm{H} \quad$ Need to increase the whole product value chain

\subsubsection{Measure Typologies}

Priorities to be tackled to ensure long-term sustainable fisheries in the area are numerous and heterogeneous. For this reason, they require the implementation of a wide and diversified range of measures, belonging to different conceptual typologies (Table 4).

Table 4. List of priorities for long-term sustainable fisheries in the area.

\begin{tabular}{|c|c|c|}
\hline & Title & Description \\
\hline 1 & Spatial measures & Measures regulating fishing with reference to specific areas \\
\hline 2 & Spatial-Temporal measures & Measures regulating fishing with reference to specific areas and periods \\
\hline 3 & Behavioral measures & $\begin{array}{l}\text { Measures sustaining good fishing practices and minimizing } \\
\text { environmental impacts }\end{array}$ \\
\hline 4 & Technical and technological improvements & $\begin{array}{c}\text { Measures concerning boats and their components, methods of navigation } \\
\text { and fishing, tools, devices, products, processes, and any element useful } \\
\text { to improve the sustainability of fishing activities }\end{array}$ \\
\hline 5 & Knowledge measures & $\begin{array}{l}\text { Aimed at increasing knowledge on the characteristics of the sea and } \\
\text { marine ecosystems in the study area, on fishing practices and their } \\
\text { effects, on other coastal and maritime activities that interact with fishing }\end{array}$ \\
\hline 6 & Monitoring, control and surveillance & $\begin{array}{c}\text { Aimed at measuring the trend of parameters relating to fishing activities } \\
\text { and the characteristics of marine ecosystems; and monitoring compliance } \\
\text { with rules and regulations relating to fishing activities in force in the } \\
\text { study area. }\end{array}$ \\
\hline 7 & Multi-level governance & $\begin{array}{l}\text { Measures aimed at improving the organization and management of } \\
\text { fishing activities; }\end{array}$ \\
\hline
\end{tabular}


Table 4. Cont.

\begin{tabular}{|c|c|c|}
\hline & Title & Description \\
\hline 8 & Regulations and administrative measures & $\begin{array}{l}\text { Measures aimed at the optimization and rationalization of regulations } \\
\text { and bureaucracy of the sector }\end{array}$ \\
\hline 9 & Economic and financial measures & $\begin{array}{c}\text { Measures dealing with economic aspects (including taxation) and aimed } \\
\text { to identify financial resources to support the performance and the } \\
\text { start-up of activities, including innovative ones (e.g., incentives, } \\
\text { financing, and indemnities) }\end{array}$ \\
\hline 10 & Entrepreneurial development and marketing & $\begin{array}{l}\text { Measures aimed at increasing the entrepreneurial capacity of operators, } \\
\text { including organizational and representative aspects, and the ability to } \\
\text { commercialize the product }\end{array}$ \\
\hline 11 & Training and engagement of operators & $\begin{array}{l}\text { Measures aimed at training of fishing operators on specific technical } \\
\text { topics and encouraging the active participation in decision-making and } \\
\text { management processes }\end{array}$ \\
\hline 12 & Education and awareness raising of the public & $\begin{array}{l}\text { Measures aimed at informing consumers about fishing activities and } \\
\text { their products, with particular reference to the seasonality of species, } \\
\text { lesser known species, the need to prefer local products, and fished with } \\
\text { sustainable techniques. }\end{array}$ \\
\hline
\end{tabular}

\subsubsection{Possible Management Measures}

A catalog of 78 measures (Appendix A, Figure 6) has been composed, belonging to one of the 12 typologies and targeting one or more of the priorities, with a predominance of those targeting Theme D-(environmental) impacts (24 measures identified). The measures concerning the training and involvement of fishermen (Type 11) represent the most numerous, followed by initiatives to improve the governance and management system of fisheries (Type 7), by initiatives aimed at increasing the entrepreneurial capacity of operators (Type 10) and by cognitive measures (Type 5).

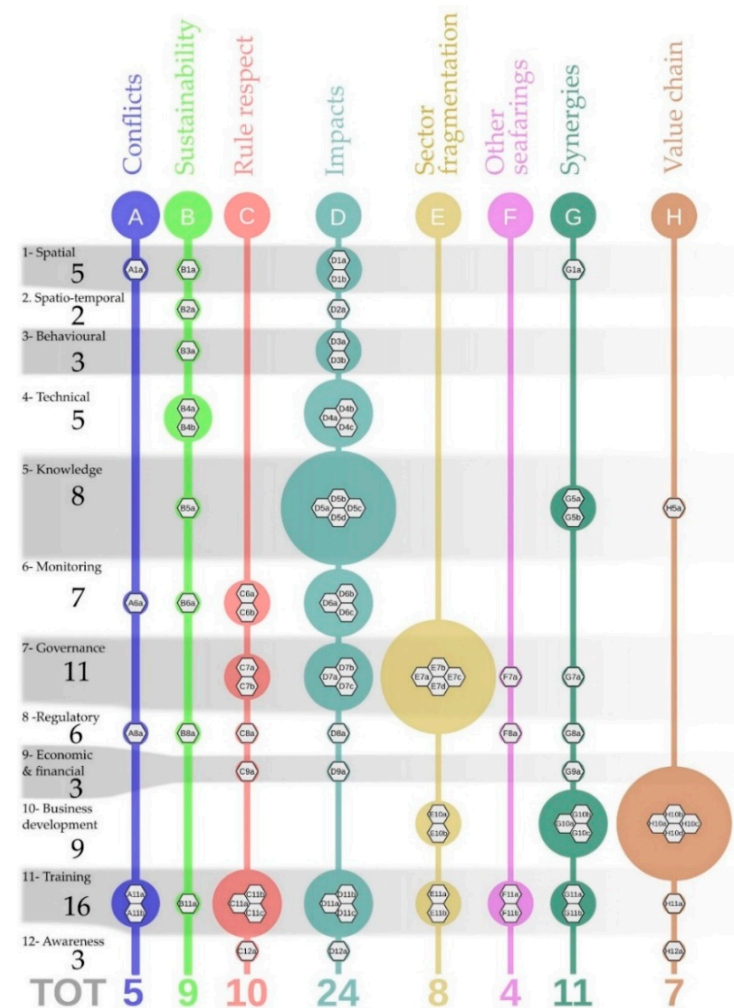

Figure 6. Graphical synthesis of proposed measures. 


\section{Discussion}

Human pressures on Mediterranean coastal and marine ecosystems have significantly increased in number and intensity during the last decades, generating the degradation of habitats of high ecological and socioeconomic value $[46,64]$. Among the intense human activities carried out in the Adriatic Sea, fisheries are those that more than others embed an added value, not only economical, but also social and historical-cultural for the entire region. Many Adriatic coastal communities have fishing and aquaculture as their primary economic activity. However, even if fishing activities have influenced the abundance of marine resources in the Adriatic for centuries [42], their recent mechanization and intensification, with a growing direct and indirect exploitation of resources [2], has increased the overall alteration of habitats and species, the reduction of biodiversity and of the main fish stocks of commercial interest [65]. In particular, numerous studies have highlighted how the fishery resources and ecosystems in the Adriatic Sea are highly vulnerable to trawling fisheries [66]. Trawling has well-documented impacts on benthic biodiversity [67], sensitive habitats, and species [68].

In this context, this study explored the potential opportunities and difficulties of applying the consolidated framework of ecosystem based maritime spatial planning (EBMSP) [14], focusing on the fishing sector in a context of multiple sea uses, such as that of the Chioggia compartment. A general long-term vision of the Adriatic Sea in a good environmental, healthy and productive status, requires proper implementation of EBM through an appropriate planning process, aimed at long-term sustainable management in order to promote conservation strategies, ensure profitability to the fishing sector, and enhance synergies with other coastal and maritime uses.

In this study, the spatially explicit analyses developed according to EB-MSP approach were able to quantitatively integrate the effect from multiple anthropogenic pressure and highlight how the whole set of human activities interacts and exerts multiple relevant biological, physical and energy related pressures to the environment.

In particular, the Cumulative Effects Assessment analysis was performed in order to inform on the propagation of pressures generated by the system of multiple anthropogenic uses and to assess the spatial distribution (i.e., footprint) of impacts exerted on environmental receptors.

Results from the tool-based analysis confirmed the general understanding available for the area about the most relevant impacting activities, but also provide, as added value, the spatial distribution of the effects on the various environmental receptors considered, and an assessment of the relative quantitative contribution of the different uses to the overall impact.

Maritime transport exerts a broad set of pressures on the case study area, mainly due to the extensive presence of shipping activities and cruise ports in the NorthernCentral Adriatic (e.g., ports of Koper, Trieste, Venice, Ravenna, and Ancona). Due to this characteristics, the maritime transport issues cannot be locally managed. Indeed, those wider influences have basin-scale features that need to be addressed in framing management measures for the overall sustainability of the maritime transport in the Adriatic-Ionian region.

Tool-based analyses allowed to spatially highlight the footprint of trawling-related disturbances in the area, that resulted in being the most important source of anthropogenic pressures and generate potential conflicts with other sectors. On the other hand, small scale fishing, representing the most relevant fishing activity in the study area in terms of average number of active vessels and employment rates, even if it extends over a limited portion of the study area, generates almost irrelevant impacts if compared to the towed gears, whose spatial footprint is spatially readily wider.

Patterns of scores detected at local scale highlight that Essential Fish Habitats (EFHs) and soft-bottom communities are the most affected by anthropogenic activities, especially those that generate mechanical damage to the seabed, extraction of species, and marine litter introduction. Seabed habitats in the Adriatic Sea host high biodiverse communities [69], 
as well as important recruitment and reproduction areas of valuable fish species [38,70], urging the need to protect the hot-spot of EFHs from the long-term effects of pressures (i.e., from bottom trawling) through the adoption of effective, area-based, and adaptive conservation measures.

Results also highlight how human activities in the case study area may affect marine turtles and bottlenose dolphins [71,72], potentially determining a wide set of effects on species, from direct mortality [73] to behavioral changes [74].

Such evidences require the adoption of management and conservation measures able to reduce the impacts of fishing on the Adriatic ecosystems, while guaranteeing its economic, productive and occupational perspectives [55]. Conservation measures should effectively address trawling-related pressures [75], aiming at a long-term maintenance of fish stocks [76] and the conservation of pelagic species in the area (especially C. caretta) [77].

Environmental protection measures imposing permanent bans or restrictions on the use of fishing techniques causing abrasion to the seabed are already in force within the case study boundaries. Towed gears are banned within a distance of $3 \mathrm{~nm}$ from the coast and inside the Special Areas of Conservation (SAC) "Tegnùe di Chioggia" (N2K IT3250047). Our results highlight however how trawling bans, in order to generate conservation benefits to fish assemblages and habitats, should be included within an adequate spatial planning framework, i.e., according to hot-spot of trawling-related pressures exerted to specific habitats and species, and accompanied by enforcement of effective control measures [35,78]. According to the fishing fleet registers of Chioggia, only 150 vessels (out of a total of 482 registered vessels) were indeed above $15 \mathrm{~m}$ in overall length (LOA), making AIS coverage for the whole fleet weak. Other specific fishing activities (e.g., hydraulic dredging), might determine significant pressures per unit of surface, but their overall contribution was not fully represented due to lack of AIS coverage. Nevertheless, vessel tracking data had proven uniquely insightful, presenting a valuable quantitative and open opportunity to well characterize fishing footprints and understand the dynamics of the fisheries sector, while fostering the need for the development of a publicly accessible registration system for fishing activities through transparent management of AIS data for all the fishing vessels. This may also improve fishermen's compliance with existing rules, entrusting the responsibility for some monitoring and control actions to stakeholders, as part of co-management schemes.

Conservation objectives in the area may be also enhanced by the introduction of other trawling restricted zones (e.g., safety regulations within $500 \mathrm{~m}$ from LNG plan, pipelines, aquaculture facilities), which could exert a synergistic effect with the existing conservation measures, being able to determine conservation benefits as "Other Effective Area-Based Conservation Measures" (OECM) [79].

The policies, strategies and regulatory framework of the European Union for the seas support the protection of marine ecosystems while promoting sustainable, planned and synergistic management of economic activities.

In example, the newly established pSCI/SAC (Habitat Directive, 92/43/EEC) site for the protection of turtles and bottlenose dolphins concerning the hot-spot area [51,74] in territorial waters facing the mouth of the River Po (Resolution No 1135 of the Veneto Regional Executive, 6 August 2020) can be a first step towards the conservation needs of the two species, especially if it will be included, together with the adjacent one in Emilia-Romagna waters (Resolution No 1572 of the Emilia-Romagna Regional Executive, 9 November 2020), in a wider protection framework in the whole Adriatic area [51]. The management of these new protection areas require a thorough application of systematic monitoring, also taking into account the seasonal variations of the Adriatic populations and accordingly applying adaptive management measures. The measures to be adopted for the fishing sector should aim at reducing the risks of interaction between fishing activities and the protected species/habitats, through spatial [80] and operational [81] limitations and specific technological improvements, such as Bycatch Reduction Devices (BRDs) [82,83], even on a seasonal basis. The new N2K site should also be appropriately managed through 
participatory governance between administrations and stakeholders, with awarenessraising and ad hoc training activities, also including research and monitoring activities.

The use of modeling tools in the analysis of fishing activities footprint [31] and of the interactions (conflicts and synergies) between fishing and other uses of the sea and of the impacts on environmental components, has proved very useful not only for the identification of possible criticalities but also to support an effective exchange with stakeholders and local authorities [55,84].

The involvement of fishermen and other key stakeholders proved to be an indispensable, but not trivial, step in the process. These activities highlighted the need to undertaking appropriate consultations within the process, in order to build trust between stakeholders and decision makers, to share objectives and management, to encourage voluntary adherence to rules and regulations, and to generate new options and solutions through the inclusion of information from diversified sources (e.g., local ecological knowledge and traditions). Once accepted as working instruments in the co-management process, toolderived results can provide objective contribution to the discussion about the elaboration of alternative management scenarios.

Conscious management choices that allow the transition to a multi-use system that gives more space to renewable resources are needed, as well as sustainable and economically advantageous activities for coastal communities (e.g., fishing tourism, initiatives to shorten the fish distribution chain, sustainable tourism, etc.). Choices that not only aim at reducing conflicts between uses and the impacts on environmental components but that are also an opportunity to develop unexpressed potential. As an example, potential conflicts between trawling and other activities, highlighted by MUC analyses, could be overtaken by policies in favor of small-scale fisheries and aquaculture, accompanying the decommissioning of the heavy trawler fleets, fostering synergies through the development of complementary activities such environmental/cultural tourism [85]. The portfolio of possible measures that can be adopted provides clear evidence that to respond to the priorities identified, it is necessary to combine and integrate different types of measures: spatial measures modulated over time, monitoring and control, actions to fill knowledge gaps, concertation - involvement-co-management actions, improvement of governance systems, actions to support innovation in the sector, etc. The identification of the main problems to be addressed in order to favor the maintenance and development of fishing activities within the framework of socio-economic and environmental sustainability has focused on identifying trends and needs and on understanding how to correctly implement the proposed measures. However, a thorough definition of measures' implications, with particular regards to their socio-economic feasibility, costs and benefits, is compelling. Economic and financial measures, together with targeted financing opportunities within the European funds for Regional Development, should be carefully considered within the composition of one or more management scenarios for fisheries, aiming to define a complete, feasible and verifiable plan of actions.

These overall needs are urgent especially considering the risks associated with the potential effects of climate change [86,87]. Complex phenomena such warming of waters, alteration of geological and oceanographic dynamics, increasingly frequent extreme meteorological phenomena, risks on the geomorphology of the delta [88], and altered hydrological dynamics of the Po river and, as a cascade, their ecological consequences on species (e.g., behavioral and life-cycles changes), habitats and ecosystems, with unpredictable effects on fish stocks [89] and on the target species of environmental protection, require to support the development and application of the best scientific knowledge with a precautionary [90], adaptive, and dynamic management.

\section{Conclusions}

The results of this research show how the use of conceptual, scientific and legal MSP processes for the management of fishing activities in the Chioggia compartment allows to enhance the coexistence with the other uses of the sea and with all the existing area-based 
conservation measures (e.g., Natura 2000 Sites), at the same time favoring the achievement of Good Environmental Status targets and the safeguarding of the fishing traditions of local communities.

The drafting of the Italian national Maritime Space Plans underway pursuant to Directive 89/2014/EU by the Technical Committee coordinated by the Ministry of Infrastructure and Transport (MSP Competent Authority) offers an opportunity in this sense, provided that this opportunity is seized and managed by the territories, with the involvement of stakeholders, and not practiced as a mere bureaucratic fulfillment.

Author Contributions: Conceptualization, G.F. (Giulio Farella), A.N.T., S.R., O.G., M.B., and A.B.; methodology, G.F. (Giulio Farella), M.B. and A.B.; software, A.N.T., S.M., and A.F.; data curation and formal analysis, G.F. (Giulio Farella), A.N.T., S.M., and C.F.; writing-original draft preparation, G.F. (Giulio Farella) and M.B.; writing—review and editing, G.F. (Giulio Farella), M.B., A.N.T., F.G., O.G., G.F. (Gianna Fabi), S.R., and A.B.; maps and visualization, G.F. (Giulio Farella), A.N.T. and A.F.; supervision, project administration, and funding acquisition, A.B. All authors have read and agreed to the published version of the manuscript.

Funding: This research was funded within the Action Plan of the FLAG GAC Chioggia Delta del Po 2014/2020, Objective 3, Specific object 5.A, Action 5.B.

Institutional Review Board Statement: Not applicable.

Informed Consent Statement: Not applicable.

Data Availability Statement: The data presented in this study are available on request from the corresponding author.

Acknowledgments: We would like to thank for the supportive collaboration of the Chioggia and Porto Tolle municipalities and the FLAG GAC Chioggia Delta del Po. We also thank for the support, knowledge exchanges and participation the colleagues Mulazzani A., Depellegrin D., Celic I., Calì F., Notti E., Pasanisi E., Franceschini G., Bearzi G., Bonizzoni S., and Mazzariol S. Special thanks go to two anonymous reviewers for their suggestions and comments that contributed to the overall improvement of the manuscript.

Conflicts of Interest: The authors declare no conflict of interest. The funders had no role in the design of the study; in the collection, analyses, or interpretation of data; in the writing of the manuscript, or in the decision to publish the results.

\section{Appendix A. Management Measures}

Appendix A.1. Issue A. Conflicts between Fishing Segments

1. Spatial measures

Measure A1a-Joint spatial planning, between different fishing categories, of coastal areas subject to fishing with set nets.

6. Monitoring, control and surveillance

Measure A6a-Development of a pilot registration system for fishing activities (Fishing vessel tracking system) through transparent management of AIS data for all the fishing vessels with LOA $>12 \mathrm{~m}$.

8. Regulations and administrative measures

Measure A8a-Preparation of a compartmental plan for fishing activities.

11. Training and engagement of operators

Measure A11a-Creation of a permanent discussion and negotiation round table.

Measure A11b-Support and training for the adoption of good practices, particularly in territorial waters.

Appendix A.2. Issue B. Sustainability of Fishing Effort

1. Spatial measures

Measure B1a-Permanent ban, with progressive and adaptive implementation, of trawling within 4 or 6 nautical miles from the coastline. 


\section{Spatial-Temporal measure}

Measure B2a-Time extension of the biological rest period for towed gears (also on a voluntary basis).

\section{Behavioral measures}

Measure B3a-Adoption of good practices on board to reduce all the accessory impacts of fishing activities (e.g., waste management).

4. Technical and technological improvements

Measure B4a-Research and introduction of technical measures aimed at reducing the impacts of all fishing techniques. mesh size).

Measure B4b-Increase in the mesh of gillnets (e.g., minimum $72 \mathrm{~mm}$ stretched

\section{Knowledge measures}

Measure B5a-Study of the spatial-temporal evolution of the fishing effort through a pilot system for recording fishing activities (Fishing vessel tracking system) in order to evaluate the sustainable effort in the area.

6. Monitoring, control and surveillance

Measure B6a-Development of a pilot registration system for fishing activities (Fishing vessel tracking system) through transparent management and live use of AIS data for all the fishing vessels with LOA $>12 \mathrm{~m}$ in order to enforce surveillance.

8. Regulations and administrative measures

Measure B8a-Administrative simplification of the licensing system, which allows the planning and application of management measures.

11. Training and engagement of operators

Measure B11a-Preparation of "living lab" initiatives and co-participatory activities, in collaboration with the Region.

\section{Appendix A.3. Issue C. Rules Enforcement}

6. Monitoring, control and surveillance

Measure C6a-Improvement of control systems for all fishing activities, including recreational ones and compliance with existing rules; where possible, participation and co-management of these systems.

Measure $\mathrm{C} 6 \mathrm{~b}-$ Entrusting the responsibility for some monitoring and control actions to stakeholders, as part of co-management schemes.

7. Multi-level governance

Measure C7a-Introduction of co-management schemes through a participatory approach and with the involvement of all the stakeholders.

Measure $\mathrm{C} 7 \mathrm{~b}-$ Creation of an operations center for verifying the adoption of space-time measures with the direct involvement of all the fisheries operators.

8. Regulations and administrative measures

Measure C8a-Definition of an administrative and regulatory process that allows the delegation from the directors to the stakeholders, in the face of increased responsibilities and in a logic of co-management.

9. Economic and financial measures

Measure C9a-Actions to support the development of co-management plans.

11. Training and engagement of operators

Measure C11a-Involvement of operators and stakeholders in participatory and co-management paths, including monitoring and control activities.

Measure $\mathrm{C} 11 \mathrm{~b}$-Promote the adoption of best practices by creating a participatory process for the definition of management measures/rules.

Measure $\mathrm{C} 11 \mathrm{c}$ - Training of operators in order to increase knowledge and compliance with the rules.

12. Education and awareness raising of the public

Measure C12a-Public meetings with operators in order to increase knowledge and compliance with the rules. 
Appendix A.4. Issue D. Impacts of Fisheries on Vulnerable Species and Valuable Environmental Components

1. Spatial measures

Measure D1a-Permanent ban, with progressive and adaptive implementation, of trawling within 4 or 6 nautical miles from the coastline.

Measure D1b-Define coastal Fishery Restricted Areas (FRAs-GFCM) with space-time modulation.

2. Spatial-Temporal measure

Measure D2a-Time extension of the biological rest period for towed gears (also on a voluntary basis).

3. Behavioral measures

Measure D3a-Reduction of hauling time ( $<90 \mathrm{~min}$ ) for trawl nets and adoption of good practices during hauling to increase the stability of the net (e.g., avoid sudden turns) in order to reduce the mortality for non-target species.

Measure D3b-Co-managed measures to reduce the abandonment/loss of fishing gears and reduce the related environmental impacts.

4. Technical and technological improvements

Measure D4a-Use of BRDs (bycatch reduction devices) and stability sensors on bottom trawling nets.

Measure D4b-Use of bycatch reduction tools (e.g., UV lamps, acoustic deterrents) on gill nets. mesh size).

Measure D4c-Increase in the mesh of gillnets (e.g., minimum $72 \mathrm{~mm}$ stretched

5. Knowledge measures

Measure D5a-Research on the distribution of target species and their life cycle and reproduction.

Measure D5b-Research on anthropogenic impacts and their space-time distributions.

Measure D5c-Experimentation of innovative techniques and technologies for monitoring and mitigating impacts.

Measure D5d-Construction of an information system to support planning and adaptive management.

6. Monitoring, control and surveillance

Measure D6a-Maintenance and strengthening of the monitoring and management system of stranded animals.

Measure D6b-Medium and long-term monitoring of the target species.

Measure D6c-Medium-long-term monitoring of the anthropogenic pressures on species and habitats.

7. Multi-level governance

Measure D7a-Promotion of a transnational action for concerted measures for the protection of bottlenose dolphins and turtles.

Measure D7b-Definition of coordinated governance between the administrations involved.

Measure D7c-Establishment of a technical-scientific table for permanent consultation.

8. Regulations and administrative measures

Measure D8a-Establishment of new Natura2000 areas in territorial waters with proper conservation measures and coherent management plans.

9. Economic and financial measures

Measure D9a-Economic compensation and conversion aid for activities affected by new environmental constraints.

11. Training and engagement of operators

Measure D11a-Direct involvement of fishermen in monitoring and control activities. 
Measure D11b-Training of fishermen for the correct management, eventual release and care of accidentally captured animals (mainly C. caretta).

Measure D11c - Direct participation of fishing operators in the management of any new protected areas.

12. Education and awareness raising of the public

Measure D12a-Implementation of awareness campaigns on the meaning, value, benefits of the environmental measures adopted.

\section{Appendix A.5. Issue E. Fragmentation of the Sector}

7. Multi-level governance

Measure E7a-Establishment of a fisheries observatory (also for joint consultation and lobbying).

Measure E7b-Promotion of the establishment or strengthening of compartmental consortia.

Measure E7c-Verification and integration of regional institutional mechanisms, in order to guarantee the recognition of sector organizations and their involvement in all activities involving the development of the sector.

Measure E7d-Promotion of the identification of one representative per fishing sector, with periodic renewal of the position, who actively participates in the management tables.

10. Entrepreneurial development and marketing

Measure E10a-Promotion of clusters, consortia, or other associations in the sector.

Measure E10b-Promotion of the development of integrated systems for the management, transformation and enhancement of the fishing products.

11. Training and engagement of operators

Measure E11a-Promotion of the aggregation of the sector through its involvement in processes relevant to the territory (MSP, infrastructural interventions, use of the coast by other sectors).

Measure E11b-Creation of training opportunities on the possible different associative modalities, providing examples of good and fruitful practices.

Appendix A.6. Issue F. Relationships with Other National and Foreign Fisheries and Common Rules

\section{Multi-level governance}

Measure F7a-Promote effective integration between local and supranational management levels in order to achieve a shared definition of rules among fisheries from different countries.

8. Regulations and administrative measures

Measure F8a-Definition of regulations to prevent conflicts in the uses of the sea between operators of different fisheries/countries.

11. Training and engagement of operators

Measure F11a-Development of training and exchange activities involving operators and representatives of fisheries from different countries.

Measure F11b-Promotion of interactions between different fisheries (both national and international) that can access to specific funds, through the initiative of local management bodies such as FLAGs and EMFFs.

Appendix A.7. Issue G. Synergies between Fishing, Aquaculture and Other Uses of the Sea

1. Spatial measures

Measure G1a-Creation of new artificial reefs with multiple functions (protection, increase in biodiversity, touristic use).

5. Knowledge measures 
Measure G5a-Study and experimentation of innovative economic activities related to the fishing sector (e.g., marine biotechnologies; use of products and waste materials from fishing activities, processing, and distribution of the product).

Measure G5b-Studies to evaluate the contribution to environmental protection of areas used for mussel farming.

7. Multi-level governance

Measure G7a-Organization of working groups between institutions and operators in the sectors interested in the development of multi-use (how to undertake bureaucratic and administrative procedures).

8. Regulations and administrative measures

Measure G8a-Inclusion in the Management Plans of environmentally important areas of measures to regulate access to fisheries.

9. Economic and financial measures

Measure G9a-Creation of targeted financing opportunities within the European funds for Regional Development, for the development of multi-use activities, including, for example, financing for the adaptation of boats to pesca-tourism.

10. Entrepreneurial development and marketing

Measure G10a-Creation of clusters of operators from fishery / aquaculture/tourism to develop pilot cases of multi-use (also including restaurants and other catering services).

Measure G10b-Promotion of synergies with the sport fishing sector

Measure G10c-Promotion of an experiential tourism offer, linked to multi-use.

11. Training and engagement of operators

Measure G11a-Creation of training opportunities on multi-use for operators of the fishing sector.

Measure G11b-Creation of training opportunities on innovative activities (marine biotechnologies, circular economy).

\section{Appendix A.8. Issue H. Need to Increase the Whole Product Value Chain}

\section{Knowledge measures}

Measure H5a-Study on how to enhance less consumed species, also through their transformation into "ready-to-use" products.

10. Entrepreneurial development and marketing

Measure H10a-Introduction of labeling systems for the geographical origin and environmental quality. for wholesales.

Measure $\mathrm{H} 10 \mathrm{~b}$ - Testing and introduction of electronic and on-line auctions

Measure H10c-Promotion of direct sale and creation of synergies with local distribution.

Measure H10d-Development of integrated systems for the management and transformation of the product, and for the increase of its product value.

11. Training and engagement of operators

Measure H11a-Training of operators on the enhancement of the product in conditions of reduced withdrawal. Simulations of theoretical cases.

Measure H11a-Training of operators on the enhancement of the product in conditions of reduced withdrawal. Simulations of practical cases.

12. Education and awareness raising of the public

Measure H12a-Implementation of consumer information campaigns (consumption of species of lesser commercial interest, consumption of sustainable and seasonal fish, and attention to traditions).

\section{References}

1. Jouffray, J.; Blasiak, R.; Norstrom, A.; Osterblom, H.; Nystrom, M. The Blue Acceleration: The Trajectory of Human Expansion into the Ocean. One Earth 2020, 2, 43-54. [CrossRef]

2. Colloca, F.; Cardinale, M.; Maynou, F.; Giannoulaki, M.; Scarcella, G.; Jenko, K.; Bellido, J.M.; Fiorentino, F. Rebuilding Mediterranean fisheries: A new paradigm for ecological sustainability. Fish 2013, 14, 89-109. [CrossRef] 
3. Fortibuoni, T.; Giovanardi, O.; Pranovi, F.; Raicevich, S.; Solidoro, C.; Libralato, S. Analysis of long-term changes in a Mediterranean marine ecosystem based on fishery landings. Front. Mar. Sci. 2017, 4, 33. [CrossRef]

4. White, P.S.; Pickett, S.T.A. Natural disturbance and patch dynamics: An introduction. In The Ecology of Natural Disturbance and Patch Dynamics; White, P.S., Pickett, S.T.A., Eds.; Academic Press: New York, NY, USA, 1985.

5. Jennings, S.; Kaiser, M.J. The effects of fishing on marine ecosystems. Adv. Mar. Biol. 1998, 34, 201-352.

6. FAO. The State of World Fisheries and Aquaculture; FAO: Rome, Italy, 2018; 244p.

7. Amoroso, R.O.; Pitcher, C.R.; Rijnsdorp, A.D.; Mcconnaughey, R.A.; Parma, A.M.; Suuronen, P.; Eigaard, O.R.; Bastardie, F.; Hintzen, N.T.; Althaus, F.; et al. Bottom trawl fishing footprints on the world's continental shelves. Proc. Natl. Acad. Sci. USA 2018, 115, E10275-E10282. [CrossRef]

8. UNEP. 2015. United Nations Environment Programme Mediterranean Action Plan. Adriatic Sea ecology. In Proceedings of the Twelfth Meeting of Focal Points for Specially Protected Areas, Athens, Greece, 25-29 May 2015.

9. Pascoe, S.; Bustamante, R.; Wilcox, C.; Gibbs, M. Spatial fisheries management: A framework for multi-objective qualitative assessment. Ocean Coast Manag. 2009, 52, 130-138. [CrossRef]

10. Meaden, G.J.; Aguilar-Manjarrez, J.; Corner, R.A.; O'Hagan, A.M.; Cardia, F. Marine Spatial Planning for Enhanced Fisheries and Aquaculture Sustainability-Its Application in the Near East; FAO Fisheries and Aquaculture Technical Paper; FAO: Rome, Italy, 2016.

11. Gavaris, S. Fisheries management planning and support for strategic and tactical decisions in an ecosystem approach context. Fish. Res. 2009, 100, 6-14. [CrossRef]

12. Asche, F.; Garlock, T.M.; Anderson, J.L.; Bush, S.R.; Smith, M.D.; Anderson, C.M.; Chu, J.; Garrett, K.A.; Lem, A.; Lorenzen, K.; et al. Three pillars of sustainability in fisheries. Proc. Natl. Acad. Sci. USA 2018, 115, 11221-11225. [CrossRef]

13. Kritzer, J.P. Influences of at-sea fishery monitoring on science, management, and fleet dynamics. Aquac. Fish. 2020, 5, 107-112. [CrossRef]

14. Ehler, C.; Douvere, F. Marine Spatial Planning: A step-by-step approach toward ecosystem-based management. Intergovernmental Oceanographic Commission and Man and the Biosphere Programme. In IOC Manual and Guides No. 53, ICAM Dossier No 6; UNESCO: Paris, France, 2009.

15. Foley, M.M.; Halpern, B.S.; Micheli, F.; Armsby, M.H.; Caldwell, M.R.; Crain, C.M.; Prahler, E.; Rohr, N.; Sivas, D.; Beck, M.W.; et al. Guiding ecological principles for marine spatial planning. Mar. Policy 2010, 34, 955-966. [CrossRef]

16. Ansong, J.; Gissi, E.; Calado, H. An approach to ecosystem-based management in maritime spatial planning process. Ocean Coast Manag. 2017, 141, 65-81. [CrossRef]

17. Long, R.D.; Charles, A.; Stephenson, R.L. Key principles of marine ecosystem-based management. Mar. Policy 2015, 57, 53-60. [CrossRef]

18. Janßen, H.; Bastardie, F.; Eero, M.; Hamon, K.G.; Hinrichsen, H.-H.; Marchald, P.; Nielsen, J.R.; Le Pape, O.; Schulze, T.; Simons, S.; et al. Integration of fisheries into marine spatial planning: Quo vadis? Estuar. Coast. Shelf Sci. 2018, 201, 105-113. [CrossRef]

19. Stelzenmüller, V.; Rogers, S.I.; Mills, C.M. Spatio-temporal patterns of fishing pressure on UK marine landscapes, and their implications for spatial planning and management. ICES J. Mar. Sci. 2008, 65, 1081-1091. [CrossRef]

20. Bastardie, F.; Nielsen, J.R.; Eigaard, O.R.; Fock, H.O.; Jonsson, P.; Bartolino, V. Competition for marine space: Modelling the Baltic Sea fisheries and effort displacement under spatial restrictions. ICES J. Mar. Sci. 2015, 72, 824-840. [CrossRef]

21. Menegon, S.; Depellegrin, D.; Farella, G.; Gissi, E.; Ghezzo, M.; Sarretta, A.; Venier, C.; Barbanti, A. A modelling framework for MSP-oriented cumulative effect assessment. Ecol. Indic. 2018, 91, 171-181. [CrossRef]

22. Russo, T.; D’Andrea, L.; Franceschini, S.; Accadia, P.; Cucco, A.; Garofalo, G.; Gristina, M.; Parisi, A.; Quattrocchi, G.; Sabatella, R.F.; et al. Simulating the Effects of Alternative Management Measures of Trawl Fisheries in the Central Mediterranean Sea: Application of a Multi-Species Bio-economic Modeling Approach. Front. Mar. Sci. 2019, 6, 542. [CrossRef]

23. Pınarbaşı, K.; Galparsoro, I.; Borja, Á.; Stelzenmüller, V.; Ehler, C.N.; Gimpel, A. Decision support tools in marine spatial planning: Present applications, gaps and future perspectives. Mar. Policy 2017, 83, 83-91. [CrossRef]

24. Nygård, H.; van Beest, F.M.; Bergqvist, L.; Carstensen, J.; Gustafsson, B.G.; Hasler, B.; Schumacher, J.; Schernewski, G.; Sokolov, A.; Zandersen, M.; et al. Decision-Support Tools Used in the Baltic Sea Area: Performance and End-User Preferences. Environ. Manag. 2020. [CrossRef]

25. Bastardie, F.; Nielsen, J.R.; Miethe, T. DISPLACE: A dynamic, individual-based model for spatial fishing planning and effort displacement-integrating underlying fish population models. Can. J. Fish. Aquat. Sci. 2014, 71, 366-386. [CrossRef]

26. Benaka, L.R.L.; Sharpe, L.; Abrams, K.; Campbell, M.; Cope, J.; Darby, F.; Dick, E.J.; Hyde, J.; Linton, B.; Lunsford, C.; et al. Action Plan for Fish Release Mortality Science; United States Department of Commerce, NOAA: Washington, DC, USA, 2016; 34p.

27. Stelzenmüller, V.; Coll, M.; Cormier, R.; Mazaris, A.D.; Pascual, M.; Loiseau, C.; Claudet, J.; Katsanevakis, S.; Gissi, E.; Evagelopoulos, A.; et al. Operationalizing risk-based cumulative effect assessments in the marine environment. Sci. Total Environ. 2020, 724, 138118. [CrossRef] [PubMed]

28. Hodgson, E.E.; Halpern, B.S. Investigating cumulative effects across ecological scales. Conserv. Biol. 2019, 33, 22-32. [CrossRef] [PubMed]

29. Stelzenmüller, V.; Lee, J.; South, A.; Rogers, S.I. Practical tools to support marine spatial planning: A review and some prototype tools. Mar. Policy 2013, 38, 214-227. [CrossRef] 
30. Said, A.; Trouillet, B. Bringing 'Deep Knowledge' of Fisheries into Marine Spatial Planning. Marit. Stud. 2020, $19,347-357$. [CrossRef]

31. Ferrà, C.; Tassetti, A.N.; Grati, F.; Pellini, G.; Polidori, P.; Scarcella, G.; Fabi, G. Mapping change in bottom trawling activity in the Mediterranean Sea through AIS data. Mar. Policy 2018, 94, 275-281. [CrossRef]

32. Ferrà, C.; Tassetti, A.N.; Armelloni, E.N.; Galdelli, A.; Scarcella, G.; Fabi, G. Using AIS to attempt a quantitative evaluation of unobserved trawling effort in the Mediterranean Sea GSA. Front. Mar. Sci. 2020, 7, 580612. [CrossRef]

33. Taconet, M.; Kroodsma, D.; Fernandes, J.A. Global Atlas of AIS-Based Fishing Activity_Challenges and Opportunities; FAO: Rome, Italy, 2019.

34. Russo, T.; Franceschini, S.; D’Andrea, L.; Scardi, M.; Parisi, A.; Cataudella, S. Predicting Fishing Footprint of Trawlers From Environmental and Fleet Data: An Application of Artificial Neural Networks. Front. Mar. Sci. 2019, 6, 670. [CrossRef]

35. Tassetti, A.N.; Ferrà, C.; Fabi, G. Rating the effectiveness of fishery-regulated areas with AIS data. Ocean Coast Manag. 2019, 175, 90-97. [CrossRef]

36. Kroodsma, D.A.; Mayorga, J.; Hochberg, T.; Miller, N.A.; Boerder, K.; Ferretti, F.; Wilson, A.; Bergman, B.; White, T.D.; Block, B.A.; et al. Tracking the global footprint of fisheries. Science 2018, 359, 904. [CrossRef]

37. Sala, E.; Mayorga, J.; Costello, C.; Kroodsma, D.; Palomares, M.L.D.; Pauly, D.; Sumaila, U.R.; Zeller, D. The economics of fishing the high seas. Sci. Adv. 2018, 4, eaat2504. [CrossRef]

38. Bastardie, F.; Angelini, S.; Bolognini, L.; Fuga, F.; Manfredi, C.; Martinelli, M.; Nielsen, J.R.; Santojanni, A.; Scarcella, G.; Grati, F. Spatial planning for fisheries in the Northern Adriatic: Working toward viable and sustainable fishing. Ecosphere 2017, 8, e01696. [CrossRef]

39. D’Andrea, L.; Parisi, A.; Fiorentino, F.; Garofalo, G.; Gristina, M.; Cataudella, S.; Russo, T. R: An r package for spatial modelling of fisheries and scenario simulation of management strategies. Methods Ecol. Evol. 2020, 11, 859-868. [CrossRef]

40. Schultz-Zehden, A.; Weig, B.; Lukic, I. Maritime Spatial Planning and the EU's Blue Growth Policy: Past, Present and Future Perspectives. In Maritime Spatial Planning; Zaucha, J., Gee, K., Eds.; Springer International Publishing: Cham, Switzerland, 2019; pp. 121-149.

41. Newell, R.I.E.; Ott, J.A. Macrobenthic Communities and Eutrophication. In Ecosystems at the Land-Sea Margin: Drainage Basins to Coastal Sea; Malone, T.C., Malej, A., Harding, L.W., Smodlaka, N., Turner, E., Eds.; Coastal and Estuarine Studies; American Geophysical Union: Washington DC, USA, 1999; Volume 55, pp. 265-293.

42. Fortibuoni, T.; Libralato, S.; Raicevich, S.; Giovanardi, O.; Solidoro, C. Coding Early Naturalists' Accounts into Long-term Fish Community Changes in the Adriatic Sea (1800-2000). PLoS ONE 2010, 5, e15502. [CrossRef] [PubMed]

43. Tosi, L.; Zecchin, M.; Franchi, F.; Bergamasco, A.; Da Lio, C.; Baradello, L.; Mazzoli, C.; Montagna, P.; Taviani, M.; Tagliapietra, D.; et al. Paleochannel and beach-bar palimpsest topography as initial substrate for coralligenous buildups offshore Venice, Italy. Sci. Rep. 2017, 7, 1321. [CrossRef]

44. Colloca, F.; Garofalo, G.; Bitetto, I.; Facchini, M.T.; Grati, F.; Martiradonna, A.; Mastrantonio, G.; Nikolioudakis, N.; Ordinas, F.; Scarcella, G.; et al. The Seascape of Demersal Fish Nursery Areas in the North Mediterranean Sea, a First Step Towards the Implementation of Spatial Planning for Trawl Fisheries. PLoS ONE 2015, 10, e0119590. [CrossRef]

45. Antonini, C.; Donadelli, V.; Finocchiaro, G.; Giovanrdi, O.; Marino, G.; Raicevich, S.; Tomasetti, P. Stock Ittici in Sovrasfruttamento. Capitolo 2. Pesca ed Acquacoltura. Annuario Dei Dati Ambientali 2019. 2020. p. 1. Available online: https://annuario isprambiente.it/sites/default/files/pdf/2019/versione-integrale/02-Pesca-2019.pdf (accessed on 15 November 2020).

46. Micheli, F.; Halpern, B.S.; Walbridge, S.; Ciriaco, S.; Ferretti, F.; Fraschetti, F.; Lewison, R.; Nykjaer, L.; Rosenberg, A. Cumulative Human Impacts on Mediterranean and Black Sea Marine Ecosystems: Assessing Current Pressures and Opportunities. PLoS ONE 2013, 8, e79889. [CrossRef]

47. EMODnet Human Activities, Download Services. Available online: https://www.emodnet-humanactivities.eu/ (accessed on 1 May 2019).

48. EMODnet Seabed Habitats. Download services. Available online: https://www.emodnet.eu/seabed-habitats (accessed on 1 May 2019).

49. Tools4MSP Data Portal. Available online: http://data.tools4msp.eu/ (accessed on 1 September 2020).

50. Menegon, S.; Depellegrin, D.; Farella, G.; Sarretta, A.; Venier, C.; Barbanti, A. Addressing cumulative effects, maritime conflicts and ecosystem services threats through MSP-oriented geospatial webtools. Ocean Coast Manag. 2018, 163, 417-436. [CrossRef]

51. Fortuna, C.M.; Cañadas, A.; Holcer, D.; Brecciaroli, B.; Donovan, G.P.; Lazar, B.; Mo, G.; Tunesi, L.; Mackelworth, P.C. The Coherence of the European Union Marine Natura 2000 Network for Wide-Ranging Charismatic Species: A Mediterranean Case Study. Front. Mar. Sci. 2018, 5, 356. [CrossRef]

52. Telesca, L.; Belluscio, A.; Criscoli, A.; Ardizzone, G.; Apostolaki, E.; Fraschetti, S.; Gristina, M.; Knittweis, L.; Martin, C.; Pergent, G.; et al. MAREA PROJECT: MEDISEH (Mediterranean Sensitive Habitats) Specific Contract No 2 (SI2.600741); Final Report; Hellenic Centre for Marine Research: Heraklion, Greece, 2013.

53. Umgiesser, G.; Melaku Canu, D.; Cucco, A.; Solidoro, C. A finite element model for the Venice Lagoon. Development, set up, calibration and validation. J. Mar. Syst. 2004, 51, 123-145. [CrossRef]

54. Depellegrin, D.; Menegon, S.; Farella, G.; Ghezzo, M.; Gissi, E.; Sarretta, A.; Venier, C.; Barbanti, A. Multi-objective spatial tools to inform maritime spatial planning in the Adriatic Sea. Sci. Total Environ. 2017, 609, 1627-1639. [CrossRef] 
55. Farella, G.; Menegon, S.; Fadini, A.; Depellegrin, D.; Manea, E.; Perini, L.; Barbanti, A. Incorporating Ecosystem Services conservation into a scenario-based MSP framework: An Adriatic case study. Ocean Coast Manag. 2020, 193, 105230. [CrossRef]

56. Moore, S.A.; Brown, G.; Kobryn, H.; Strickland-Munro, J. Identifying conflict potential in a coastal and marine environment using participatory mapping. J. Environ. Manag. 2017, 197, 706-718. [CrossRef] [PubMed]

57. Menegon, S.; Sarretta, A.; Depellegrin, D.; Farella, G.; Venier, C.; Barbanti, A. Tools4MSP: An open source software package to support Maritime Spatial Planning. PeerJ 2018, 4, e165. [CrossRef]

58. Judd, A.; Backhaus, T.; Goodsir, F. An effective set of principles for practical implementation of marine cumulative effects assessment. Environ. Sci. Policy 2015, 54, 254-262. [CrossRef]

59. Raicevich, S.; Dubois, M.; Bullo, M.; Franceschini, G.; Mion, M.; Nalon, N.; Piras, C.; Sabatini, L.; Fortibuoni, T.; Celić, I.; et al. The Italian Job: Navigating the (Im)Perfect Storm of Participatory Fisheries Research in the Northern Adriatic Sea. In Collaborative Research in Fisheries; Holm, P., Hadjimichael, M., Linke, S., Mackinson, S., Eds.; MARE Publication Series; Springer: Cham, Switzerland, 2020; Volume 22.

60. Twomey, S.; O'Mahony, C. Stakeholder Processes in Marine Spatial Planning: Ambitions and Realities from the European Atlantic Experience. In Maritime Spatial Planning; Zaucha, J., Gee, K., Eds.; Palgrave Macmillan: Cham, Switzerland, 2019.

61. Morf, A.; Kull, M.; Piwowarczyk, J.; Gee, K. Towards a Ladder of Marine/Maritime Spatial Planning Participation. In Maritime Spatial Planning; Zaucha, J., Gee, K., Eds.; Palgrave Macmillan: Cham, Switzerland, 2019.

62. Farella, G.; Raicevich, S.; Bocci, M.; Tassetti, A.N.; Menegon, S.; Giovanardi, O.; Ferrà, C.; Grati, F.; Fabi, G.; Barbanti, A. Progetto NORA-Sviluppo di strumenti a sostegno della governance partecipata degli usi del mare nel Compartimento marittimo di Chioggia. PdA FLAG GAC Chioggia Delta del Po 2014-2020. Final. Rep. 2019, 175. [CrossRef]

63. Piras, C.; Mion, M.; Fortibuoni, T.; Franceschini, G.; Punzo, E.; Strafella, P.; Despalatović, M.; Cvitković, I.; Raicevich, S. A photographic method to identify benthic assemblages based on demersal trawler discards. Fish. Res. 2016, 178, $142-151$. [CrossRef]

64. Coll, M.; Piroddi, C.; Albouy, C.; Ben Rais Lasram, F.; Cheung, W.W.L.; Christensen, V.; Karpouzi, V.S.; Guilhaumon, F.; Mouillot, D.; Paleczny, M.; et al. The Mediterranean Sea under siege: Spatial overlap between marine biodiversity, cumulative threats and marine reserves. Glob. Ecol. Biogeogr. 2012, 21, 465-480. [CrossRef]

65. Fortibuoni, T.; Libralato, S.; Arneri, E.; Giovanardi, O.; Solidoro, C.; Raicevich, S. Fish and fishery historical data since the 19th century in the Adriatic Sea, Mediterranean. Sci Data 2017, 4, 170104. [CrossRef]

66. Pranovi, F.; Raicevich, S.; Franceschini, G.; Farrace, M.G.; Giovanardi, O. 'Rapido' trawling in the northern Adriatic Sea: Effects on benthic communities in an experimental area. ICES J. Mar. Sci. 2000, 57, 517-524. [CrossRef]

67. Oberle, F.K.; Storlazzi, C.D.; Hanebuth, T.J. What a drag: Quantifying the global impact of chronic bottom trawling on continental shelf sediment. J. Mar. Syst. 2016, 159, 109-119. [CrossRef]

68. Russo, T.; Carpentieri, P.; D’Andrea, L.; De Angelis, P.; Fiorentino, F.; Franceschini, S.; Garofalo, G.; Labanchi, L.; Parisi, A.; Scardi, M.; et al. Trends in Effort and Yield of Trawl Fisheries: A Case Study From the Mediterranean Sea. Front. Mar. Sci. 2019, 6, 153. [CrossRef]

69. Santelli, A.; Cvitković, I.; Despalatović, M.; Fabi, G.; Grati, F.; Marčeta, B.; Punzo, E.; Raicevich, S.; Strafella, P.; Spagnolo, A.; et al. Spatial distribution and temporal persistence of megazoobenthos assemblages in the Adriatic Sea. Mar. Ecol. Prog. Ser. 2017, 566, 31-48. [CrossRef]

70. Grati, F.; Scarcella, G.; Polidori, P.; Domenichetti, F.; Bolognini, L.; Gramolini, R.; Vasapollo, C.; Giovanardi, O.; Raicevich, S.; Celić, I.; et al. Multi-annual investigation of the spatial distributions of juvenile and adult sole (Solea solea L.) in the Adriatic Sea (northern Mediterranean). J. Sea Res. 2013, 84, 122-132. [CrossRef]

71. Bearzi, G.; Fortuna, C.M.; Reeves, R.R. Ecology and conservation of common bottlenose dolphins Tursiops truncatus in the Mediterranean Sea. Mammal Rev. 2008, 39, 92-123. [CrossRef]

72. Casale, P.; Freggi, D.; Furii, G.; Vallini, C.; Salvemini, P.; Deflorio, M.; Totaro, G.; Raimondi, S.; Fortuna, C.; Godley, B. Annual survival probabilities of juvenile loggerhead sea turtles indicate high anthropogenic impact to Mediterranean populations. Aquatic Conserv: Mar. Freshw. Ecosyst. 2015, 25, 690-700. [CrossRef]

73. Lucchetti, A.; Angelini, V.; Furii, G.; Pari, S.; Vasapollo, C.; Virgili, M. Evidence of loggerhead sea turtle (Caretta caretta, Linnaeus, 1758) injuries caused by Rapido (beam) trawling in the Mediterranean. Herpetol. J. 2018, 28, 134-136.

74. Bonizzoni, S.; Furey, N.B.; Bearzi, G. Bottlenose dolphins (Tursiops truncatus) in the north-western Adriatic Sea: Spatial distribution and effects of trawling. Aquat. Conserv. Mar. Freshw Ecosyst. 2020, 1-16. [CrossRef]

75. Dureuil, M.; Boerder, K.; Burnett, K.A.; Froese, R.; Worm, B. Elevated trawling inside protected areas undermines conservation outcomes in a global fishing hot spot. Science 2018, 362, 1403-1407. [CrossRef]

76. Scarcella, G.; Grati, F.; Raicevich, S.; Russo, T.; Gramolini, R.; Scott, R.D.; Polidori, P.; Domenichetti, F.; Bolognini, L.; Giovanardi, O.; et al. Common sole in the northern and central Adriatic Sea: Spatial management scenarios to rebuild the stock. J. Sea Res. 2014, 89, 12-22. [CrossRef]

77. Lucchetti, A.; Pulcinella, J.; Angelini, V.; Pari, S.; Russo, T.; Cataudella, S. An interaction index to predict turtle bycatch in a Mediterranean bottom trawl fishery. Ecol. Ind. 2016, 60, 557-564. [CrossRef]

78. Agnetta, D.; Badalamenti, F.; D’Anna, G.; Sinopoli, M.; Andaloro, F.; Vizzini, S.; Pipitone, C. Sizing up the role of predators on Mullus barbatus populations in Mediterranean trawl and no-trawl areas. Fish. Res. 2019, 213, 196-203. [CrossRef] 
79. Shabtay, A.; Portman, M.E.; Manea, E.; Gissi, E. Promoting ancillary conservation through marine spatial planning. Sci. Total Environ. 2019, 651, 1753-1763. [CrossRef] [PubMed]

80. O'Keefe, C.E.; Cadrin, S.X.; Stokesbury, K.D.E. Evaluating effectiveness of time/area closures, quotas/caps, and fleet communications to reduce fisheries bycatch. ICES J. Mar. Sci. 2014, 71, 1286-1297. [CrossRef]

81. Santana-Garcon, J.; Wakefield, C.B.; Dorman, S.R.; Denham, A.; Blight, S.; Molony, B.W.; Newman, S.J. Risk versus reward: Interactions, depredation rates and bycatch mitigation of dolphins in demersal fish trawls. Can. J. Fish. Aquat. Sci. 2018, 75, 2233-2240. [CrossRef]

82. Lucchetti, A.; Sala, A. An overview of Loggerhead sea turtle (Caretta caretta) bycatch and technical mitigation measures in the Mediterranean Sea. Rev. Fish Biol. Fish. 2009, 20, 141-161. [CrossRef]

83. Wakefield, C.B.; Santana-Garcon, J.; Dorman, S.R.; Blight, S.; Denham, A.; Wakeford, J.; Molony, B.W.; Newman, S.J. Performance of bycatch reduction devices varies for chondrichthyan, reptile, and cetacean mitigation in demersal fish trawls: Assimilating subsurface interactions and unaccounted mortality. ICES J. Mar. Sci. 2017, 74, 343-358. [CrossRef]

84. Muñoz, M.; Reul, A.; Gil de Sola, L.; Lauerburg, R.A.M.; Tello, O.; Gimpel, A.; Stelzenmüller, V. A spatial risk approach towards integrated marine spatial planning: A case study on European hake nursery areas in the North Alboran Sea. Mar. Environ. Res. 2018, 142, 190-207. [CrossRef]

85. Depellegrin, D.; Venier, C.; Kyriazi, Z.; Vassilopoulou, V.; Castellani, C.; Ramieri, E.; Bocci, M.; Fernandez, J.; Barbanti, A. Exploring Multi-Use potentials in the Euro-Mediterranean sea space. Sci. Total Environ. 2019, 653, 612-629. [CrossRef]

86. Ramírez, F.; Coll, M.; Navarro, J.; Bustamante, J.; Green, A.J. Spatial congruence between multiple stressors in the Mediterranean Sea may reduce its resilience to climate impacts. Sci. Rep. 2018, 8, 14871. [CrossRef]

87. Frazão Santos, C.; Agardy, T.; Andrade, F.; Calado, H.; Crowder, L.B.; Ehler, C.N.; García-Morales, S.; Gissi, E.; Halpern, B.S.; Orbach, M.K.; et al. Integrating climate change in ocean planning. Nat. Sustain. 2020, 3, 505-516. [CrossRef]

88. Da Lio, C.; Tosi, L. Vulnerability to relative sea-level rise in the Po river delta (Italy). Estuar. Coast. Shelf Sci. 2019, $228,106379$. [CrossRef]

89. Gaines, S.D.; Costello, C.; Owashi, B.; Mangin, T.; Bone, J.; Molinos, J.G.; Burden, M.; Dennis, H.; Halpern, B.S.; Kappel, C.V.; et al. Improved fisheries management could offset many negative effects of climate change. Sci. Adv. 2018, 4, 8-eaao1378. [CrossRef] [PubMed]

90. Gissi, E.; Menegon, S.; Sarretta, A.; Appiotti, F.; Maragno, D.; Vianello, A.; Depellegrin, D.; Venier, C.; Barbanti, A. Addressing uncertainty in modelling cumulative impacts within maritime spatial planning in the Adriatic and Ionian region. PLoS ONE 2017, 12, e0180501. [CrossRef] [PubMed] 